\title{
Konfiskationsloven - myte og praksis
}

Af Karen Harder LiLDHOLdT

Den 30. marts 1946 vedtog den danske rigsdag lov nr. 132 af 30. marts 1946 om konfiskation af tysk og japansk ejendom. Omfanget af japansk ejendom var beskedent, så det blev derfor konfiskation af tyske værdier, der blev helt dominerende. Loven var affødt af unormale omstændigheder og gennemførelsen af loven en nødvendighed. Men hvordan blev loven administreret i praksis? Dette giver cand.mag. Karen Harder Lildholdt på baggrund af en analyse af 221 enkeltsager i Gråsten retskreds et kvalificeret bud på. Artiklen er en omarbejdet og forkortet udgave af forfatterens speciale.

Baggrunden for lov om konfiskation af tysk og japansk ejendom var de allieredes erstatningskrav mod Tyskland for skader, forvoldt under 2. Verdenskrig. Danmarks samlede erstatningskrav til Tyskland blev i sommeren 1945 opgjort til 11,6 mia. kr. Konfiskationsloven faldt uden for normal dansk og vesteuropæisk retspraksis, og den blev ikke etableret som et ønske fra dansk politisk side eller som krav fra befolkningen, men efter pres udefra, primært fra USA. ${ }^{1}$ Det samlede antal konfiskationssager i Danmark udgjorde knapt 20.000, hvoraf 3.500 sager blev annulleret eller overført til andre sager. ${ }^{2}$ Der findes således netto ca. 16.500 sager.

Det er den hidtidige forsknings vurdering, at Danmark administrerede loven meget strengt. Men denne vurdering baserer sig primært på enkeltsager, som har spillet en fremtrædende rolle i den offentlige debat, og det har ført til den almindelige - men misvisende - opfattelse, at tyske statsborgere generelt blev frataget alle ejendele.

Nogle af de omtaler, der har haft indflydelse på den offentlige mening, er omtalerne af konfiskationen af godserne Fussingø og Kalø, hvor bl.a. professor Ditlev Tamm i en kronik i Jyllands-Posten den 26. april 1997 skrev om "Den skandaløse konfiskation af tysk ejendom «. Det konkrete emne var konfiskationen af godserne Fussingø og Kalø, men senere i kronikken anføres, at »konfiskation af tysk ejendom fandt sted automatisk. Ikke noget med at overveje i hvert enkelt tilfælde, om der var tale om tysk, fjendtlig ejendom. Al tysk ejendom 
var i sig selv fjendtlig og blev dermed konfiskeret«. Dette er for så vidt helt korrekt, fordi de danske politikere havde besluttet, at al tysk ejendom skulle betragtes som fjendtlig og derfor konfiskeres. Først herefter kunne den tyske statsborger søge dispensation og sandsynliggøre, at han/hun ikke havde opført sig fjendtligt over for Danmark. I sin kronik beskrev Ditlev Tamm herefter dispensationsmulighederne, men undlod at gøre opmærksom på, at alle herboende tyske statsborgere $\mathrm{i}$ henhold til konfiskationsloven havde adgang til at friholde en del af deres formue for konfiskation ("udtagelsesret"). Som det senere vil fremgå, var der her tale om en meget stor gruppe tyske statsborgere, der helt undgik konfiskation.

I Gads leksikon om dansk besættelsestid 1940-45 har historikeren Joachim Lund i en artikel beskrevet, hvorledes der kunne dispenseres, når der var tale om ejendom tilhørende personer, der ikke kunne betragtes som fjendtlige - f.eks. tyskere, der havde været forfulgt af det nazistiske regime ${ }^{3}$. Men han konkluderer, at praksis generelt var streng. Lund skriver endvidere, at antinazistiske familiers ejendom blev konfiskeret, og at andre motiver end de rent økonomiske formentlig spillede ind, f.eks. når kvinder, der havde giftet sig med tyske soldater, fik konfiskeret deres opsparing, blot fordi de ved giftermålet automatisk havde fåt tysk statsborgerskab. Lund henviser i en note til en artikel af Gunnar Kjær Mortensen, der har beskrevet, hvorledes en ung kvinde på grund af sit ægteskab med en tysk soldat fik konfiskeret sine få ejendele ${ }^{4}$. Joachim Lund slutter dog sin artikel med en bemærkning om, at området savner nærmere udforskning.

Også professor Stig Jørgensens artikel i Information den 4. oktober 1994 har medvirket til opfattelsen af, at Danmark administrerede loven meget strengt, når han skrev, at »tyske statsborgere, hvis slægt havde boet i Danmark i generationer og som havde opført sig eksemplarisk under besættelsen, fik konfiskeret hele deres ejendom «.

Denne fokusering på enkeltsager har gjort indtryk på den offentlige mening. Opfattelser, der ikke er nedskrevne, er vanskeligere at dokumentere. Men endnu i dag er det en gængs opfattelse, både hos danske og måske navnlig hos tysksindede, ikke mindst i den ældre generation, at konfiskationsloven blev administreret strengt, og at tyske statsborgere fik frataget alt, hvad de ejede.

Denne artikel bygger på en gennemgang af 221 enkeltsager fra Gråsten retskreds. Her blev konfiskationsloven administreret af landsretssagfører Kristian Lind, Gråsten, der var såkaldt "stedfortrædende 
kommissarius", udpeget af kommissarius i København. Gråsten-sagerne omfatter samtlige konfiskationssager for hele retskredsen gennem hele perioden, og man kan her følge den omfattende korrespondance vedrørende administrationen af konfiskationsloven. Foruden Gråstensagerne er artiklen baseret på en gennemgang af de tilsvarende centraladministrative sager fra kommissarius' eget arkiv, der i dag findes på Rigsarkivet, dispensationsnævnets referater samt revisionsprotokollaterne, hvoraf en del har givet væsentlige oplysninger om praksis i forbindelse med administrationen af konfiskationsloven. Den foreliggende undersøgelse er således baseret på et bredere kildegrundlag og tegner et andet og mere nuanceret billede end den hidtidige forskning.

\section{Rigsdagen og lovgivningen}

På Jalta-konferencen i februar 1945 blev "De tre store« - USA, USSR og Storbritannien - enige om at søge erstatning for de skader, Tyskland havde forvoldt under 2. Verdenskrig. På Potsdam-konferencen i juni 1945 blev det bestemt, at Rusland og Polen skulle søge dækning af deres krav i de russiskbesatte områder, mens USA, Storbritannien og andre lande skulle fyldestgøres fra de vestlige zoner og de hertil egnede aktiver i fremmede lande. På de vestallieredes konference i Paris 9. november til 21. december 1945 underskrev Danmark slutprotokollen, hvorefter Danmark ikke alene havde ret til at konfiskere alle tyske fjendtlige aktiver, men også pligt til at sørge for, at disse ikke på nogen måde kunne falde tilbage til tysk ejendomsret eller tysk kontrol.

Stærkt presset af navnlig USA fremlagde handelsminister Villemoes den 31. januar 1946 forslag til lov om konfiskation af tysk og japansk ejendom. ${ }^{5}$ Ministeren lagde ikke skjul på, at der også var en økonomisk baggrund for fremsættelsen af lovforslaget. Danske tilgodehavender og værdier i Storbritannien og USA havde under krigen været indefrosset og var endnu ikke blevet frigivet, men regeringen forventede, at dette ville ske i forbindelse med vedtagelsen af lovforslaget om konfiskation. Danmark måtte nu som én af de allierede nationer og som medlem af De Forenede Nationer være med til at skaffe delvis dækning for de tab, Tyskland havde påført de enkelte lande. Det internationale mål var nu dels at kompensere de skadelidte lande for deres tab, dels at forhindre, at der uden for Tyskland kunne findes basis for at opbygge en økonomi, der i givet fald kunne blive 


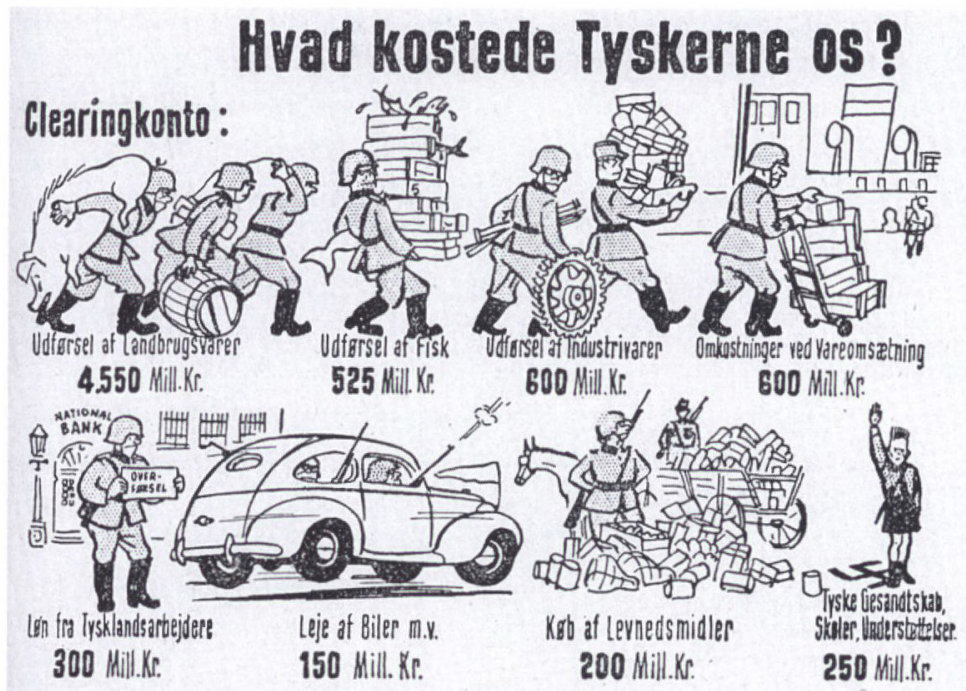

Diverse Udgifter $\mathbf{3 2 5}$ Mill. Kr. ialt $\mathbf{7 . 5 0 0 ~ M i l l . K r . ~}$

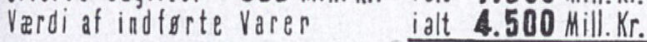
3000 kid..Ke.

Vernemantskonto (diverse Debitoper):

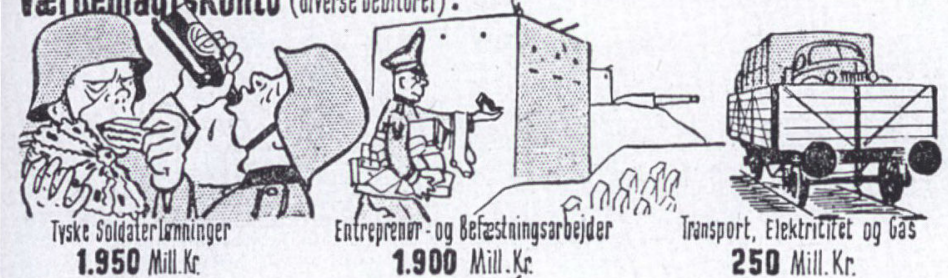

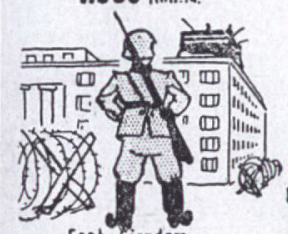

Fast Eiendom

150 kill. Kr.

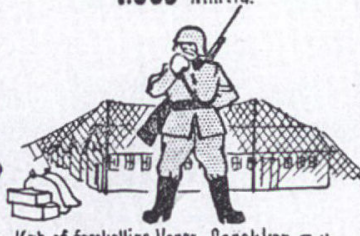

Keb of forskellige Varei, barakker m.v. 150 Mill. Kr.

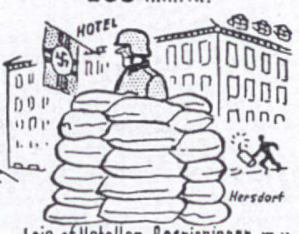

Leje af Hoteller, Bespisninger m.v. 250 Mill. Kr

4.650 Mill.K: Harens og Flaadens Materiel, Şchaiburgtage m.v. ca. 3.000 Mill.kr. Tilsammen ca. 11.000Nill.K.

Årbogen "Hvem-Hvad-Hzor " fra Politikens Forlag anskueliggjorde i 1946 i tal, tekst og tegning fordelingen af de summer, den tyske besættelse havde kostet det danske samfund. 
springbræt for en ny tysk økonomisk ekspansion, som igen ville kunne danne grundlag for ny politisk aggression. Baggrunden herfor var, at man fra tysk side før krigen bevidst havde søgt at skaffe sig indflydelse på erhvervslivet $i$ andre lande for derigennem at kunne tvinge også fremmede landes erhvervsliv til at arbejde for tyske interesser. $^{6}$

Tyske værdier i Danmark skønnedes at udgøre ca. 114 mio. kr. og japanske $100.000 \mathrm{kr}^{7}$ Tallet var behæftet med stor usikkerhed, fordi provenuet også afhang af omfanget af dispensationer og de usikkerhedsmomenter, der lå $i$ lovens $\S 25$, der indebar, at man ved konfiskation skulle respektere skyldige skatter, offentlige afgifter, panterettigheder m.v. samt legitime krav, der kunne rejses mod de tidligere tyske ejere.

Ved første behandling af lovforslaget fremgik det klart, at ingen politikere $\mathbf{i}$ grunden ønskede denne lov, men at man indså nødvendigheden heraf. Der var massiv modstand mod lovforslagets overskrift "Lov om konfiskation af tysk og japansk ejendom«. Samtlige ordførere onskede en ordlyd, der var begrænset til "tysk, fjendtlig ejendom «. Samtidig blev det dog tilkendegivet, at hvis det ikke lykkedes at ændre ordlyden, ville man lægge afgørende vægt på lovens dispensationsbestemmelser. Dette var der bred enighed om $i$ folketingssalen. ${ }^{8}$ Der kom dog også direkte anmodninger om, at de Vogelgesangske ejendomme i Sønderjylland blev inddraget under loven og udstykket. Chr. Norlev fra Retsforbundet fremsatte det ønske, at den Vogelgesangske virksomhed fik »dødsstødet« med denne lovgivning. ${ }^{9}$

Minister for særlige anliggender, Per Federspiel, var i anden anledning i London i januar 1946, hvor han forsøgte at forklare briterne det urimelige $i$, at tyske statsborgere, der havde boet $\mathrm{i}$ Danmark på lovlig vis og ikke havde forset sig på anden måde end ved at være tyskere, skulle stilles ringere end tyskere i Tyskland. Federspiel kæmpede også for en dispensationsmulighed for det danske mindretal i Sydslesvig og fremhævede de særlige forhold, der gjorde sig gældende her. Men briterne bøjede sig kun så langt, at danskerne »skulle ordne sagen herhjemme, men blot således, at vi gik så stille som overhovedet muligt med dørene ${ }^{10}{ }^{10}$ Pariseraftalens ordlyd - "Enhver af signaturmagterne skal under de former, den måtte vælge, tilbageholde eller likvidere tyske, fjendtlige aktiver inden for dens jurisdiktion på en sådan måde, at disse aktiver ikke kan falde tilbage til tysk ejen- 
domsret eller tysk kontrol« - skulle således ikke tages bogstaveligt, som om hver enkelt regering selv kunne opstille regler for, hvilken fremgangsmåde og regler man ville følge.

\section{Kommissarius og administrationen}

Til at forestå administrationen af konfiskationsloven blev der oprettet en midlertidig stilling som kommissarius samt et konfiskationsnævn, der skulle bistå kommissarius ved realisationen af konfiskeret ejendom. ${ }^{11}$ I samråd med nævnet skulle kommissarius tage stilling til eventuel tilbagelevering af konfiskeret ejendom. Landsretsdommer Jens Herfelt ${ }^{12}$ blev udnævnt som den første kommissarius.

Det var et stort apparat, der skulle sættes i værk. Antallet af sager og den dertil hørende arbejdsbelastning kan vurderes ud fra antallet af ansatte gennem årene. Specielt de to første år betød en voldsom arbejdsmængde, der krævede 100 ansatte. Men allerede i 1950 var antallet reduceret til 21 og i 1959 var der kun kommissarius selv og to halvdagsansatte. ${ }^{13}$ Arbejdet foregik i et tæt samarbejde med politiet.

Der blev oprettet en sag for hver eneste tysk statsborger, der ikke var omfattet af undtagelsesbestemmelsen. Sagerne indeholder fortrykte skemaer, hvor den pågældende tyske statsborger skulle redegøre for sine formueforhold. Hvor der foreligger svar ses, at mange kun ejede værdier af beskedent omfang. Mange henvendelser blev returneret som uanbringelige på grund af død, flytning mv., og der gik da en proces i gang med at forsøge at spore dem. Det viste sig undertiden, at en del af de tilskrevne var eller var blevet danske statsborgere ved lov eller ægteskab. Nogle var statsløse, østrigske, tjekkoslovakiske osv.

Når det var konstateret, at der var grundlag for konfiskation, udpegede kommissarius ad hoc lokale sagførere til at varetage statens interesser, men i Sønderjylland valgte kommissarius en anden organisation. Den 4. maj 1946 udsendte han en skrivelse til sagførerne Gregers Rosenstand i Aabenraa retskreds, Jacob Miang i Sønderborg retskreds og Kristian Lind i Gråsten retskreds og tilsvarende skrivelser til de derværende politimestre og dommere samt til amtmanden, hvori han bekræftede, at der var indgået en aftale om, at de tre sagførere skulle være hans stedlige repræsentanter således, at hver sagfører var bemyndiget til inden for hver deres retskreds at foretage de skridt til varetagelse af statens interesser med hensyn til den konfiskerede ejen- 
Landsretssagforer Kristian Lind blev $i$ maj 1946 udpeget som "stedfortrædende kommissarius" for Grästen retskreds. Det betod, at det var ham, der administrerede konfiskationslozen $i$ retskredsen. När administrationen af lowen $i$ Sonderjylland blev organiseret som en slags lokal forvaltning, skyldtes det koncentrationen af tyske statsborgere. (Foto: Gristen lokalhistoriske Forening har venligst formidlet udlan af fotografiet, der er i privateje).

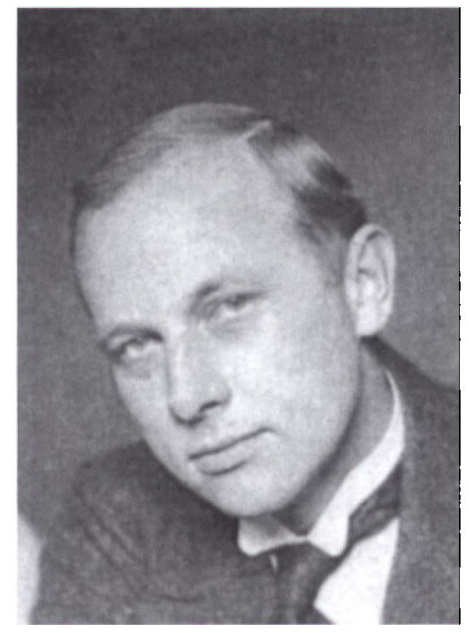

dom, som de fandt nødvendige. ${ }^{14}$ Tilsvarende skrivelser blev senere sendt til de samme persongrupper $i$ andre sønderjyske retskredse.

Årsagen til, at administrationen af loven i Sønderjylland blev organiseret som en slags lokal forvaltning, var, som vi skal se, koncentrationen af tyske statsborgere.

\section{Hvem var omfattet af loven?}

Tyske, flygtede statsborgere af jødisk afstamning, der var anerkendt som flygtninge af de Samvirkende Danske Emigranthjælpekomiteer, var undtaget fra konfiskationsloven. Ellers var alle tyske statsborgere i princippet omfattet af konfiskationsloven. Men i bemærkningerne til lovens $\S 5$ hedder det, at »der kunne forekomme tilfælde, hvor det ville være ubilligt at konfiskere tysk ejendom, fordi denne ikke med rette kunne betegnes som fjendtlig «, nemlig f.eks. ejendom, der tilhørte medlemmer af det danske mindretal syd for grænsen. Desuden kunne der også for i Danmark bosiddende tyske statsborgere eller forhenværende tyske statsborgere foreligge forhold, der giorde det ønskeligt og naturligt at fritage dem fra konfiskation af deres ejendom, f.eks. hvis det drejede sig om politiske flygtninge eller danskfødte kvinder, der var eller havde været gift med tyske statsborgere. Dertil kom rent praktiske problemer med at afgøre en given persons statslige tilhørsforhold. Rigspolitiets fremmedafdeling havde efter en 
længere afbrydelse kun fungeret i kort tid, og heller ikke folkeregistrene havde helt styr på borgernes statsborgerforhold.

\section{Hvilken slags ejendom faldt ind under loven?}

I realiteten var alle værdier, der tilhørte tyske statsborgere, hjemfalden til konfiskation, medmindre værdierne tilhørte personer, der havde boet eller opholdt sig i Danmark på tidspunktet for vedtagelse af konfiskationsloven. Loven gav disse tyske statsborgere ret til at udtage »de for den pågældende og hans husstand fornødne gangklæder, linned, senge og sengeklæder samt indbogenstande, der efter forholdene er nødvendige til opretholdelse af et tarveligt hjem for den pågældende og hans husstand, og endelig - inden for en samlet værdi af $2.000 \mathrm{kr}$ - - genstande, som i øvrigt hører til de vigtigste livsfornødenheder eller er nødvendige for udøvelsen af den pågældendes næringsvej, herunder kontante midler«. Det skal her bemærkes, at 2.000 $\mathrm{kr}$. med udgangspunkt i det daværende lønniveau skønnes at svare til ca. 80.000 kr. i $2008 .^{15}$

\section{Konfiskeret ejendom ${ }^{16}$}

Hvis en tysk statsborger ejede mere end det, der var omfattet af udtagelsesretten, havde kommissarius principielt ret til at konfiskere vedkommendes værdier. Praksis var dog at stille sagen $i$ bero en kort tid for at afvente en eventuel ansøgning om dispensation.

Konfiskeret ejendom måtte ikke henligge uden opsyn, den måtte ikke forringes, og der skulle ske en vedligeholdelse, så den ikke mistede sin værdi. Konsekvenserne af denne bestemmelse var, at tyske ejere af fast ejendom for eksempel ikke kunne opkræve eller modtage husleje, vedligeholde ejendom eller bestille håndværkere. Disse funktioner blev nu udlagt til varetagelse af kommissarius og dennes stedfortrædere, og dette fik, som vi skal se, stor indflydelse på dagligdagen på den stedfortrædende kommissarius' kontor i Gråsten. Herefter var det meningen, at de konfiskerede værdier skulle sælges. Statens Jordlovsudvalg blev som regel tilbudt køb af de store gårde. Fast ejendom blev overtaget uden særlig vurdering til ejendomsskyldværdien pr. 1. oktober 1945 med et tillæg af $20 \%$, for ubebyggede grunde dog med et tillæg på $10 \%$. Realisation af fast ejendom, som staten ikke selv ønskede at overtage, blev solgt ved offentligt udbud i lighed 
med al anden konfiskeret, fast ejendom og som regel til det højeste bud. ${ }^{17}$ Den konfiskerede ejendom skulle fortrinsvis sælges til danske statsborgere, og salg måtte ikke ske til personer eller virksomheder, som var dømt eller under tiltale eller sigtelse for overtrædelse af tillæg til borgerlig straffelov (Landssvigerlovene) samt personer, der havde udvist "unational optræden « under krigen.

Børsnoterede aktier og obligationer blev solgt til de officielt noterede kursværdier. Smykker, ure og lignende værdigenstande, konfiskeret uden for Sønderjylland, blev solgt gennem Charlottenborgs kunstauktioner for højeste bud. Indbo blev udbudt efter brandforsikringsværdien, men salgspriserne lå langt under disse. Biler blev solgt efter en forudgående vurdering gennem Direktoratet for Vareforsyning, og varelagre, maskiner og lignende blev solgt enten underhånden efter indhentet tilbud eller på en auktion.

\section{Dispensation}

Regeringen valgte at gennemføre en lovgivning med dispensationsmulighed. Som tidligere nævnt, var det noget, den danske regering havde måttet slås for. Rent praktisk blev der oprettet et dispensationsnævn, der kunne indstille til handelsministeren om at fritage ejendom, der tilhørte »retssubjekter, som findes ikke at kunne betragtes som fjendtlige « fra konfiskation. ${ }^{18}$ Hvis en tysk statsborger således ejede mere end de værdier, der faldt ind under konfiskationslovens bestemmelser om udtagelsesret, havde vedkommende adgang til at søge om dispensation, hvis der forelå særlige grunde, og han kunne godtgøre, at han ikke havde udvist en fjendtlig holdning mod Danmark.

Allerede under Rigsdagens behandling af konfiskationsloven var der tilslutning til, at medlemmer af det danske mindretal syd for grænsen skulle betragtes som ikke-fjendtlige over for Danmark, ligesom danskfødte kvinder, som var eller havde været gift med tyske statsborgere, måtte kunne betragtes som ikke-fjendtlige, for så vidt de pågældende i enhver henseende havde opført sig korrekt over for Danmark.

Ansøgningsblanketter om dispensation kunne fås på politikontorerne og skulle sendes med påtegning af skattemyndigheden direkte til dispensationsnævnet, der videresendte sagen til politimyndighederne gennem rigspolitichefens fremmedafdeling. Hvor ægtefæller havde særeje, skulle ansøgning om dispensation ske separat for hver ægtefælle. Det var derefter politiets opgave at forhøre nærmere om ansøgerens 
forhold, det være sig hos naboer, arbejdsgivere og -kolleger m.fl. Dette var nok ikke behageligt for ansøgeren, men det kunne undertiden falde ud til hans fordel, hvis omtalen generelt var positiv. Adgangen til disse rapporter har været meget begrænset, men i visse sager har dispensationsansøgernes advokat fået adgang til materialet. For Sønderjyllands vedkommende blev også kommunalbestyrelsen hørt, og før færdigbehandling blev justitsministeriet hørt om opholds- og arbejdstilladelse. Det var ikke noget under, at sagsbehandlingstiden i dispensationsnævnet var lang og undertiden kunne vare $1-1 \frac{1}{2}$ år.

Hver sag blev underkastet en individuel prøvelse, og hovedkriteriet, der lå til grund for fritagelse for konfiskation, var en vurdering af den pågældendes tilhørsforhold og holdning til den danske nation. Et særligt modsætningsforhold til det nazistiske Tyskland kunne ligeledes tale til fordel for en dispensation. Medlemskab af nazipartiet eller frivilligt arbejde for tyskerne under besættelsen udelukkede ikke ubetinget, men dog normalt fra dispensation. For tyske statsborgere i grænseegnene var der en tilbøjelighed til at slække kravet om upåklagelig national holdning noget. Her var det som regel tilstrækkeligt for at opnå dispensation, at det blot var godtgjort, at man i national henseende havde forholdt sig roligt og passivt. At have opholdstilladelse medførte ikke ubetinget en dispensation. I en række tilfælde afslog man ansøgningen om dispensation, fordi de foreliggende oplysninger viste en fjendtlig holdning over for Danmark. Når ansøgernes statsborgerlige forhold var genstand for behandling af danske myndigheder, og der var en sandsynlighed for, at ansøgeren var dansk eller ville blive naturaliseret, skulle nævnet anbefale en udsættelse.

Tyske statsborgere, der havde fået dansk indfødsret efter 30. marts 1946, fik altid dispensation. Tyske statsborgere af jødisk afstamning, der ikke kunne betragtes som flygtninge, fik normalt dispensation, og politiske emigranter blev behandlet på linje hermed.

Danskfødte, tyskgifte kvinder, fik en lidt forskelligartet behandling alt efter, hvornår de havde indgået ægteskab. Herboende enker og fraskilte, der havde giftet sig før besættelsen, fik fuld dispensation, og fra 1947 fik andre danskfødte, tyskgifte kvinder med bopæl i Tyskland deres konfiskerede formue konverteret til en livrente, så pengene kunne komme kvinden og ikke hendes mand eller børn til gode. For indbo, personlige effekter, smykker og lignende og for allerede bestående livrenter og legatportioner samt for kapitalbeløb af indtil 6-7.000 kr. blev der uanset hovedreglen meddelt fuldstændig dispensation. 
Livrenteordningen blev forladt i 1948/49, og der blev nu normalt givet danskfødte, tyskgifte kvinder, hvad enten de havde bopæl i Danmark eller Tyskland, fuld dispensation med hensyn til deres formue her i landet. Forudsætningen var dog en opfattelse af, at den danskfødte kvinde ikke kunne tillægges fjendtlige holdninger over for Danmark. Ændringen i praksis over for danskfødte kvinder var et led $\mathrm{i}$ den almindelige lempelse $\mathrm{i}$ dispensationspraksis.

Tyske statsborgere, som efter justitsministeriets almindelige praksis skulle have været udvist af landet, men af humanitære grunde havde fået opholdstilladelse på grund af for eksempel alder, sygdom og lignende, blev meddelt en delvis dispensation $i$ form af livsvarig brugsret til deres huse, livrente, frigivelse af indbo eller en del af den beslaglagte formue mv.

Med hensyn til ejendomme i Sonderjylland, der tilhørte personer med bopæl her, fulgte handelsministeriet og dispensationsnævnet en lempelig praksis på grund af de særlige forhold i landsdelen. Der blev ligeledes fulgt en lempelig praksis med hensyn til ansøgere, bosat $i$ Sydslesvig, enten med familie- eller anden personlig tilknytning til Danmark eller som ejer af jord, som blev delt ved grænsedragningen i 1920, eller jord, der var arvet. I disse sager arbejdede dispensationsnævnet sammen med de sydslesvigske organisationer og havde et samarbejde med de sønderjyske folketingsmænd om de sønderjyske sager. Allerede i 1950 var der bevilget fritagelse for konfiskation for al ejendom nord for grænsen tilhørende sydslesvigere, der stod i en dansk organisation før 1945. Sidste frist for fritagelse for konfiskation var den 31. august 1959.

\section{Sønderjylland}

I Sønderjylland fik loven en helt speciel betydning på grund af den store koncentration af tyske statsborgere, der ejede ejendom her. Der var ca. 6.300 fastboende tyske statsborgere i Danmark og knap 1.000 personer, der formodedes sidst at have haft tysk statsborgerskab, samt knap 1.000 personer, der på grund af jødisk herkomst havde fået frataget deres tyske statsborgerskab. Omtrent 1.900 af de tyske statsborgere i Danmark boede i Sonderjylland. Her havde nationalitetskampen mellem dansk og tysk været i gang siden 1840'erne og kampen om jorden siden 1890'erne. I Sønderjylland var ca. 900 ejen- 
domme ejet af udenlandske, primært tyske, statsborgere, der ligeledes havde et stort antal værdier stående i banker m.v.

\section{Jordkampen}

Jordkampen i Sønderjylland drejede sig ikke alene om agerjord, men også om sindelag og i den sidste ende om grænsespørgsmålet. I de forste år efter 1864 havde de nye, tyske magthavere travlt med de administrative forandringer af de nyvundne områder, men fra 1880 'erne begyndte en fortyskningsproces af landsdelen. Et led i denne proces var, at der 1893-1920 blev lagt et helt bælte af prøjsiske såkaldte domænegårde over Sønderjylland, hvis forpagtere skulle fungere som en tysk overklasse af »junkere «. ${ }^{19}$ I 1912 vedtog den preussiske landdag en lov om styrkelse af tyskheden i bl.a. Sønderjylland. ${ }^{20}$ Man prøvede sig også frem med oprettelse af nybyggerbrug, og i 1912 kom også den såkaldte "Bindelov«, der skulle sikre statens forkøbsret $\mathrm{i}$ låntagerens ejendom.

Ved Genforeningen blev de 36 prøjsiske domænegårde på i alt 6.400 ha overtaget af den danske stat og udstykket lidt efter lidt. Dette medførte naturligt nok, at dansk sprog og kultur fik en større plads end tidligere. For at modvirke, at tyskheden nu blev rullet tilbage, oprettedes Kreditanstalt Vogelgesang i 1926 på initiativ af det tyske mindretal. ${ }^{21}$ Hensigten var ikke blot at hjælpe tyske landsmænd i nød, men tillige at gå aktivt frem og sikre sig jord ved at udlåne kapital til tysksindede bønder, der ville købe jord i grænseområdet, navnlig $i$ "den truede firkant «. ${ }^{22}$ Som modvægt mod dette angreb på jorden oprettedes den 24. januar 1927 det danske »Landeværnet«, der skulle søge at låne kapital ud til dansksindede bønder. Landeværnet blev dannet af mænd fra de sønderjyske sogne, men foreningens formål blev snart en national opgave, og midlerne kom i høj grad fra det øvrige Danmark. Midlerne var dog slet ikke af samme omfang som det, Kreditanstalt Vogelgesang og dets datterselskab Höfeverwaltungsgesellschaft kunne præstere. Det har vist sig, at kreditanstalten havde millioner af tyske mark til sin rådighed. Pengene kom for størstedelen fra den tyske stat med banker og selskaber i Tyskland, Holland og Schweiz som mellemled. ${ }^{23}$ Indtil 1945 fik Kreditanstalt Vogelgesang og Höfeverwaltungsgesellschaft anbragt 7,2 mio. kr. i landbrugsejendomme i Sønderjylland. Alt sammen et led i at opkøbe jorden i en landsdel, hvor det ikke var lykkedes at vinde sjælene. 
På baggrund af 1930'ernes økonomiske situation med elendig økonomi, dårlige afsætningsmuligheder $\mathrm{i}$ udlandet og stor arbejdsløshed var også de danske landmænd i Sønderjylland i en udsat position. Det danske "Landeværnet«, der var blevet etableret for at hjælpe landsdelens danske landmænd, var ikke stærkt nok til at hamle op med den tyskfinansierede udlånsvirksomhed, der favoriserede tysksindede, der ønskede at købe ejendomme, og som stillede barske krav til danskere, der var nødt til at søge lån her. For eksempel ved at kræve, at familiens børn skulle tages ud af danske skoler og sættes i tyske. Mere symbolske krav var kravet om at nedtage familiens flagstang, så man ikke længere kunne flage med Dannebrog.

Umiddelbart efter kapitulationen begyndte centraladministrationen at indsamle oplysninger om udenlandsk ejet ejendom i Danmark. Statens Jordlovsudvalg var meget interesseret $\mathrm{i}$ at få registreret de ejendomme i Sønderjylland, der tilhørte Kreditanstalt Vogelgesang og Höfeverwaltungsgesellschaft, og som det fremgår af et fortroligt brev til dommeren i Rødding, forespurgte jordlovsudvalget allerede den 7. maj 1945 om nærmere oplysninger om ejendomme, der tilhørte de to selskaber. ${ }^{24}$ Udvalget ønskede også indberetning af navne på ejerne af de ejendomme, der i tidens løb måtte være afhændet af Vogelgesang, ejendomme, der havde lån fra Vogelgesang samt oplysninger om ejendomme, der tilhørte personer, bosat i udlandet. Ligeledes ønskede man oplysning, om retskredsen havde kendskab til stråmænd for Vogelgesang eller tyske institutioner.

De ejendomme, der tilhørte Kreditanstalt Vogelgesang eller Höfeverwaltungsgesellschaft og udenlandske statsborgere i øvrigt, var fordelt inden for retskredsene, som det fremgår af nedenstående tabel 1.

Med vedtagelsen af konfiskationsloven blev de vogelgesangske ejendomme og arealer beslaglagt, de vogelgesangske pantebreve krævedes indfriet, og ejendommene blev overtaget af Statens Jordlovsudvalg. I forbindelse med beslaglæggelsen blev det afsløret, at initiativtagerne til kreditanstalten fra begyndelsen havde set dens virke $i$ et grænseflytningsperspektiv, og at der via forskellige selskaber $i$ udlandet var kanaliseret penge fra den tyske stat til anstalten. ${ }^{25} \mathrm{I}$ likvideringen af kreditanstalten og efterfølgende konfiskation var det således regulær tysk kapital, der blev beslaglagt. Desuden blev alle private ejendomme m.v. tilhørende tyske statsborgere beslaglagt, men en stor del heraf blev siden, som vi skal se, tilbagegivet ved dispensation. 
Tabel 1: Oversigt over ejendomme tilhørende henholdsvis Kreditanstalt Vogelgesang/Höfeverwaltungsgesellschaft og andre med udenlandsk statsborgerskab.

\begin{tabular}{|l|r|r|r|}
\hline Retskreds & Nr. & $\begin{array}{r}\text { Vogelgesang/ } \\
\text { Höfe- } \\
\text { verwaltung }\end{array}$ & $\begin{array}{r}\text { Udenlandske } \\
\text { statsborgere } \\
\text { i øvrigt }\end{array}$ \\
\hline Haderslev & 89 & 14 & 171 \\
\hline Rødding & 90 & - & 18, muligvis 20 \\
\hline Toftlund & 91 & 2 & 15 \\
\hline Aabenraa & 92 & 16 & 52 \\
\hline Sønderborg & $93 / 94$ & - & 63 \\
\hline Gråsten & 95 & 34 & 192 \\
\hline Løgumkloster & 96 & 29 & 17 \\
\hline Tønder & 97 & 40 & 229 \\
\hline I alt & & 135 & 757, muligvis 759 \\
\hline
\end{tabular}

\section{Det tyske mindretal}

Ved Genforeningen fik befolkningen i Sønderjylland valget mellem at blive danske statsborgere eller at forblive tyske statsborgere (optere). Sindelagsopdelingen mellem dansk og tysk afhang imidlertid ikke af statsborgerskab.

Krigens begivenheder hører uden for denne artikels rammer, men det er nødvendigt at trække enkelte elementer frem, bl.a. mindretallets bidrag til etablering af uniformerede korps. ${ }^{26}$ Det tyske mindretal blev fra 1933 generelt nazificeret og stod $\mathrm{i}$ besættelsesårene værnemagten bi. I januar 1943 begyndte mindretallet hvervningen til Zeitfreiwilligendienst, en slags uniformeret hjemmeværn, som skulle bistå regulære tyske tropper i tilfælde af en allieret invasion i Danmark. Efter kapitulationen var det belastende for hele korpset, at Zeitfreiwillige havde udførte patruljetjeneste under forskellige uroligheder, fordi tjenesten i disse tilfælde var vendt mod danske medborgere. Et andet hjemmetysk korps var Selbstschutz, der blev oprettet i 1944 og udstyret med uniform og våben. Korpset udførte vagtopgaver, bl.a. ved virksomheder, som arbejdede for den tyske værnemagt. Selbst- 
schutz var betydelig mere ideologisk, dvs. nazistisk, betonet end Zeitfreiwillige-korpset, og det var en skærpende omstændighed for medlemmerne, at de bl.a. havde tiltaget sig politimyndighed over for danske medborgere. ${ }^{27}$

Efter kapitulationen stillede Det sønderiydske Raad, dannet af den sønderjyske modstandsbevægelse, vidtgående krav til behandlingen af de tyske nordslesvigere. Alle, der havde handlet mod danske interesser, skulle straks udvises, dog skulle krigsforbrydere først afsone deres straf, og på særlige præmisser skulle det være muligt at fratage en hjemmetysker hans danske statsborgerskab med efterfølgende udvisning til Tyskland. Rådet præciserede, at det skulle umuliggøres udenlandske statsborgere og institutioner direkte eller indirekte at erhverve jord eller anden fast ejendom i de sønderjyske landsdele. ${ }^{28}$ Det sønderjydske Raad fik stor folkelig opbakning til sine synspunkter, men andre sønderjyder med mere moderate holdninger talte imod og gav udtryk for, at man som naboer skulle kunne leve sammen i fremtiden. Vreden og bitterheden mod naboen gjorde imidlertid, at retsopgøret i Sønderjylland havde en særlig intensitet. Den danske holdning var præget af mistro og afstandtagen. I hjemmetysk selvforståelse var de overgreb, der var overgået dem, derimod dybt uretfærdige.

\section{Konfiskationsloven i Sønderjylland}

De sønderjyske politikere har haft indflydelse på administrationen af dispensationssagerne for så vidt angår de sønderjyske sager. Dette kan bl.a. aflæses af revisionens bemærkninger om, at ansøgninger om dispensation fra de i Sønderjylland bosatte tyske statsborgere af dispensationsnævnet for en række af disse sagers vedkommende er drøftet med de sønderjyske rigsdagsmænd, inden indstilling til handelsministeriet er afgivet. ${ }^{29}$ Ligeledes blev de såkaldte "sydslesvigske sager «, som omfattede de i Sydslesvig bosatte tyske statsborgere, der ejede ejendom nord for grænsen, af nævnet udskilt til evt. særskilt behandling. Revisor anfører her, at det drejer sig om ca. 500 sager.

\section{Gråsten retskreds}

I Gråsten retskreds boede ca. 170 voksne tyske statsborgere, svarende til knap $1 / 10$ af de tyske statsborgere i Sønderjylland. ${ }^{30}$ I retskredsen lå 34 af de 135 ejendomme, der ved krigens slutning var ejet af Kredit- 
forening Vogelgesang og Höfeverwaltungsgesellschaft, og 192 af de 757 ejendomme, der i øvrigt var ejet af personer med udenlandsk statsborgerskab. I Gråsten retskreds lå således i begge tilfælde godt $25 \%$ af de af landsdelens ejendomme, der var på udenlandske hænder. Dette var formentlig en af årsagerne til, at man her havde en fast "stedfortrædende kommissarius" til varetagelse af de mange sager og den omfangsrige administration, der fulgte med.

\section{Gråsten-sagerne}

Som tidligere nævnt, havde kommissarius allerede den 4. maj 1946 skriftligt bemyndiget landsretssagfører Lind i Gråsten til på hans vegne at varetage statens interesser $\mathrm{i}$ forbindelse med konfiskationssagerne i Gråsten retskreds. Sagerne blev rejst ad forskellige kanaler, de fleste dog efter en henvendelse fra kommissarius i København, der bad Lind om at foretage registrering hos en nærmere angivet tysk statsborger. Men også andre myndigheder kunne foranledige sager rejst, og f.eks. banker havde pligt til at oplyse om tilgodehavender, der tilhørte tyske statsborgere.

Når en sag var rejst, foretog Lind en registrering af den pågældende tyske statsborgers værdier, idet han på den pågældendes adresse foretog en oplistning af alle effekter i boligen, lige fra møbler til umage knive. Denne procedure blev overværet af et medbragt vidne, oftest redaktør A.P. Møller, der også fungerede som vurderingsmand. I boer med særlige værdier, f.eks. møbler, porcelæn og sølvtøj, medbragte Lind særligt sagkyndige, f.eks. en antikvitetshandler. Hustruerne fra flere tyske diplomatfamilier havde slået sig ned i retskredsen, og de havde været nødt til at placere møbler og andet indbo rundt omkring, så undertiden var det nødvendigt for Lind at foretage registrering flere steder.

I forbindelse med registreringsforretningen blev familien forespurgt, hvorvidt den havde andre værdier som fast ejendom, bankbøger, livsforsikringer m.v. Alle oplysninger blev nedskrevet, og registreringsforretningen underskrevet af familien ellers dennes repræsentant samt af Lind selv og vidnet.

Når Lind på stedet kunne vurdere, at hjemmets værdier faldt inden for konfiskationslovens bestemmelser om udtagelsesret, blev dette straks meddelt. Hvor der var tale om større værdier, der faldt ind under dispensationsbestemmelserne, gjorde Lind opmærksom på muligheden for dispensation. 


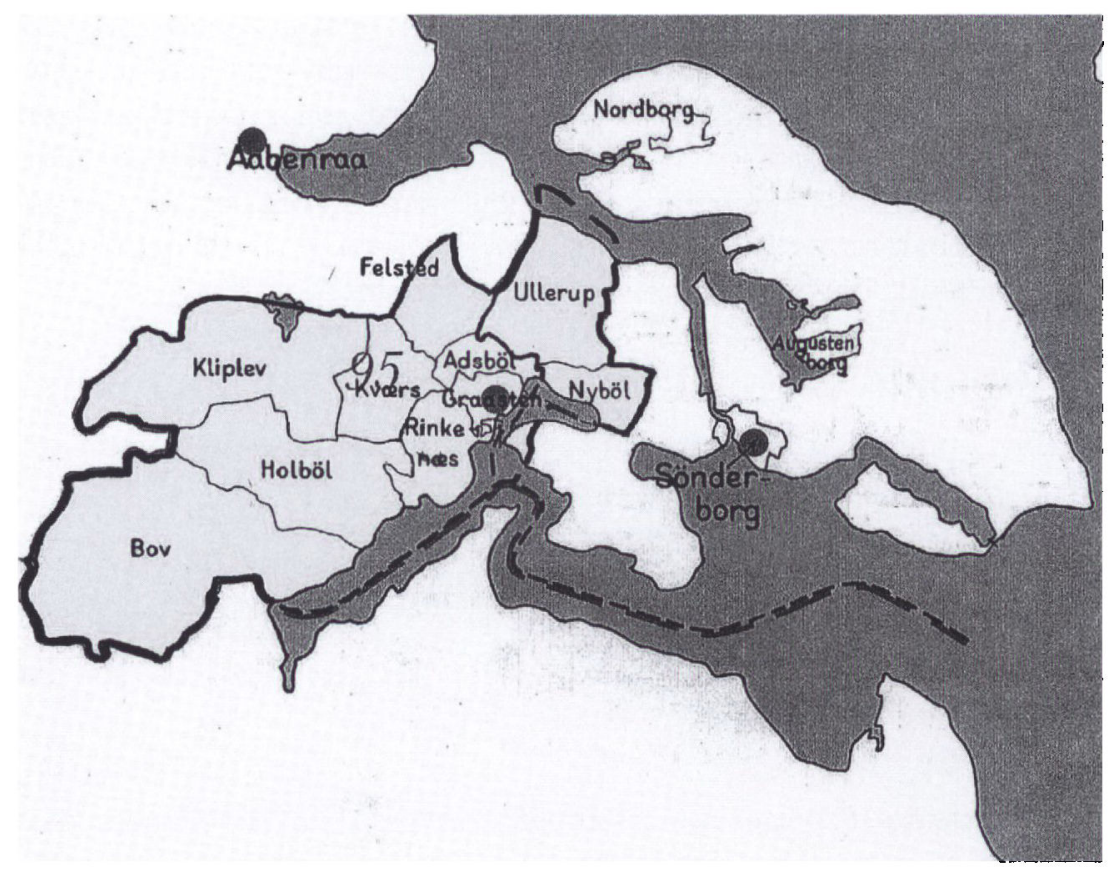

Kort over Gråsten retskreds. Artiklen bygger på en gennemgang af 221 enkeltsager fra denne retskreds. (Atlas over Danmarks administrative inddeling efter 1660).

Som repræsentant for kommissarius påhvilede det Lind at drage omsorg for, at den konfiskerede ejendom ikke forringedes $i$ værdi eller henlå uden opsyn. En ansøgning om dispensation bevirkede, at konfiskationen blev sat $\mathrm{i}$ bero, men var konfiskationen en kendsgerning, blev det konfiskerede afhændet. Konfiskeret ejendom blev sendt i offentligt udbud, og Lind fulgte den procedure at sende de indkomne bud i en lukket kuvert til kommissarius til dennes afgørelse. Lind undgik her at blive inddraget $i$ forhandlinger med lokale liebhavere til de undertiden meget attraktivt beliggende ejendomme ved Flensborg Fjord. Møbler, andet indbo og f.eks. værktøj blev bortauktioneret på offentlig auktion til højeste bud. Det fremgår af Gråsten-sagerne, at Lind undertiden har haft en særdeles omfattende administration af diverse konfiskationssager. Dette afspejler sig formentlig af hans salær for hver enkelt sag, der beløber sig fra beskedne $10 \mathrm{kr}$. til knap $900 \mathrm{kr}$. Naturligvis var arbejdsbyrden størst, hvor der har været tale om forretningsmæssig drift, men også arvesager kunne give anledning til mange og atypiske forret- 
ninger for et advokatkontor. I de mange sager, hvor de tysk ejede ejendomme var udlejet, gik både lejeforhold og vedligeholdelse af ejendommene igennem Linds advokatkontor. Da det som nævnt påhvilede Lind at drage omsorg for, at det konfiskerede ikke forringedes, måtte der nødvendigvis tages stilling til utroligt mange store og små spørgsmål, fra reparationer af tag til skorstensfejerregninger. Dette betød også en omfattende bogholderimæssig indsats fra Linds kontor.

Gråsten-sagerne består af 221 sager. Heraf er:

To ikke omfattet af konfiskationsloven ifølge afgørelse fra kommissarius.

Seks vedrører ikke konfiskationsloven.

Otte vedrører konfiskationsloven perifert.

$\mathrm{Ni}$ er henlagt af forskellige årsager.

Syv vedrører danske statsborgere.

En vedrører amerikansk statsborger.

En vedrører østrigsk statsborger.

De resterende 187 sager repræsenterer hver fra en til ti voksne personer med tysk statsborgerskab samt mindre, tyske firmaer og institutioner. Disse sager er i tabel 2 opdelt efter bopæl/hjemsted.

Tabel 2: Antal sager, fordelt på bopæl eller hjemsted for så vidt angår firmaer eller institutioner.

\begin{tabular}{|l|r|}
\hline Bopæl/hjemsted pr. sag & Antal sager \\
\hline Tyskland & 98 \\
\hline Danmark & 78 \\
\hline Tyskland og Danmark & 7 \\
\hline Andre lande & 4 \\
\hline I alt & 187 \\
\hline
\end{tabular}

Som det ses af tabel 2, vedrørte de fleste sager personer eller firmaer, der hørte hjemme i Tyskland. Lidt færre sager hørte hjemme i Danmark, og 7 sager havde en blanding af personer, der boede $i$ henholdsvis Tyskland og Danmark, oftest arvesager, hvor der også var »blandede « statsborgerforhold. Fire sager vedrørte personer med bopæl uden for henholdsvis Tyskland og Danmark. 
I de efterfølgende tabeller bruges forkortelserne DK=Danmark og $\mathrm{D}=$ Tyskland. Tabellerne indeholder forskellige oversigter, således at man direkte kan sammenligne identiske typer sager, fordelt efter forskellige kriterier. Jeg har valgt ikke at kommentere samtlige tal, men at forklare, hvad der er indeholdt i de enkelte parametre, og jeg vil trække enkelte tal frem i hver tabel.

I tabel 3 oplistes de forskellige, endelige resultater af samtlige konfiskationer, fordelt på sager fra Danmark, Danmark + Tyskland, Tyskland og Andre lande, og de er opgjort i total og med procentfordeling. Kolonnerne er ikke helt sammenlignelige, da personer, der opholdt sig eller havde opholdt sig i Danmark ved konfiskationslovens vedtagelse, havde ret til at udtage værdier $i$ henhold til lovens $\S 3$, stk. 2, hvilket ikke var tilfældet for personer, der ikke havde opholdt sig i Danmark. I næsten halvdelen af de »danske sager « - 34 ud af 78 sager - udtages samtlige værdier. Dette betyder ikke, at andre ikke havde udtaget, hvad loven tillod, men at værdierne her oversteg lovens udtagelsesret. Udtagelse er således også sket i de sager, der er registreret under "Dispensation, 1. ansøgning " m.v., og f.eks. i de sager, der er registreret under »Ikke søgt/ses ikke«. Udtagelsesretten er ligeledes effektueret $\mathrm{i}$ de »tyske sager «, hvor et voksent familiemedlem har opholdt sig i Danmark ved konfiskationslovens vedtagelse og derefter.

For så vidt angår dispensation er der i 35,8\% af samtlige sager givet dispensation ved 1. ansøgning. Ser man isoleret på de "tyske sager", er dispensationsprocenten ved 1. ansøgning oppe på 50. Procenten for endeligt afslag er på 7 for samtlige sager, højest for personer, bosat i Tyskland.

I tabel 3 ses det endelige resultat af dispensationsbehandlingen, det vil sige, at de tretten personer, der har fået afslag, har fået den endelige afgørelse. Rubrikken »Dispensation, 1. ansøgning « viser det antal personer, der har fået dispensation ved 1. ansøgning. Når der foreligger dispensation ved 2. ansøgning eller herefter, kan der have været forskellige stadier af dispensation i forløbet, således, at en familie typisk første gang kunne have fået dispensation for indbo eller penge og ved en senere ansøgning fuld dispensation, der også omfattede eventuel fast ejendom.

I en række tilfælde er der først opnået dispensation, efter at det konfiskerede er realiseret, og det har da medført, at provenuet er udbetalt. 
Tabel 3: Antal sager, fordelt efter bopæl/hjemsted og resultatet efter konfiskationen, angivet totalt og procentvis.

\begin{tabular}{|l|r|r|r|r|r|r|}
\hline $\begin{array}{l}\text { Bopæl/hjemsted } \\
\text { Resultat }\end{array}$ & DK & $\begin{array}{r}\text { DK } \\
\text { D }\end{array}$ & D & $\begin{array}{r}\text { Andre } \\
\text { lande }\end{array}$ & I alt & $\%$ \\
\hline Afslag, endeligt & 3 & & 8 & 2 & 13 & 7,0 \\
\hline Dispensation, 1. ansøgning & 17 & 1 & 49 & & 67 & 35,8 \\
\hline Dispensation, 2. ansøgning & 8 & 1 & 12 & & 21 & 11,2 \\
\hline Dispensation, 3. ansøgning & 2 & & 4 & 2 & 8 & 4,3 \\
\hline $\begin{array}{l}\text { Dispensation, 4 eller flere } \\
\text { ans. }\end{array}$ & 1 & & 1 & & 2 & 1,1 \\
\hline Disp, forskelig (arvesag) & & & 1 & & 1 & 0,5 \\
\hline Betinget/delvis dispensation & 2 & 2 & 2 & & 6 & 3,2 \\
\hline Resultat ses ikke & & & 1 & & 1 & 0,5 \\
\hline Ikke søgt/ses ikke & 7 & 2 & 17 & & 26 & 13,9 \\
\hline Alt udtaget & 30 & & & & 30 & 16,0 \\
\hline Arv udleveret & 2 & & & & 2 & 1,1 \\
\hline Mere end udtagelsesret & 2 & & & & 2 & 1,1 \\
\hline Tildelt uden udtagelsesret & & & 3 & & 3 & 1,6 \\
\hline Frigiver småbeløb & 1 & & & & 1 & 0,5 \\
\hline Sag frafaldes & 2 & & & & 2 & 1,1 \\
\hline Ukendt arving & 1 & & & & 1 & 0,5 \\
\hline Domstolsafgørelse & & 1 & & & 1 & 0,5 \\
\hline I alt & 78 & 7 & 98 & 4 & 187 & 100 \\
\hline $\begin{array}{l}\text { Heraf tidligere lærere ved } \\
\text { tyske skoler }\end{array}$ & 11 & 1 & & 12 & \\
\hline Heraf konsul/diplomat & 5 & & 1 & 1 & 7 & \\
\hline Arvesager & 4 & 6 & 8 & & 18 & \\
\hline
\end{tabular}

Betinget eller delvis dispensation dækker over en række forskellige situationer, f.eks. en situation, hvor arvinger fik udlagt arv til betaling for og vedligeholdelse af et gravsted, eller hvor en dispensation af- 
Tabel 4: Antal dispensationer fordelt efter årstal og antal ansøgninger, idet bemærkes, at samtlige dispensationer er medtaget, herunder sager, hvor det endelige resultat er blevet en betinget eller delvis dispensation.

\begin{tabular}{|l|r|r|r|r|r|}
\hline År & $\begin{array}{l}\text { 1. ansøg- } \\
\text { ning }\end{array}$ & $\begin{array}{l}\text { 2. ansøg- } \\
\text { ning }\end{array}$ & $\begin{array}{l}\text { 3. ansøg- } \\
\text { ning }\end{array}$ & $\begin{array}{l}\text { 4. ansøgning } \\
\text { eller flere }\end{array}$ & I alt \\
\hline 1947 & 3 & & & & 3 \\
\hline 1948 & 6 & 4 & 1 & & 11 \\
\hline 1949 & 7 & & & & 7 \\
\hline 1950 & 1 & 2 & 1 & & 4 \\
\hline 1951 & 26 & 4 & 1 & & 31 \\
\hline 1952 & 12 & 7 & 4 & & 1 \\
\hline 1953 & 1 & 1 & & & 24 \\
\hline 1954 & & 2 & & & 2 \\
\hline 1955 & 2 & 1 & 2 & & 2 \\
\hline 1956 & 1 & & 2 & & 1 \\
\hline 1957 & & & 1 & & 4 \\
\hline Ses ikke & 9 & & & & 1 \\
\hline I alt & 68 & 21 & 12 & & 105 \\
\hline
\end{tabular}

hang af, om ansøgeren foretog videreskødning af sin ejendom til hustru eller børn. Betinget eller delvis dispensation kom også på tale for en del tyske statsborgere, som efter justitsministeriets almindelige praksis skulle have været udvist af landet, men som af humanitære grunde - for eksempel på grund af alder eller sygdom - fik opholdstilladelse. Disse tyske statsborgere fik typisk meddelt en " delvis dispensation « $i$ form af livsvarig brugsret til deres huse, livrente, frigivelse af indbo eller en del af den beslaglagte formue mv. Det set hyppigt, at den endelige afgørelse for denne gruppe bliver fuld dispensation.

I en ret stor gruppe på i alt 26 sager er der tilsyneladende ikke sket ansøgning om dispensation. Årsagerne hertil kan være mange, bl.a. flytning og flugt under krigen, de kaotiske kommunikationsforhold lige efter krigen, dødsfald samt selvfølgelig det forhold, at nogle vidste, at deres situation ikke kunne betinge en dispensation eller, at 
Tabel 5: Antal sager for personer/firmaer i henholdsvis Danmark (DK) og Tyskland (D), fordelt efter resultatet efter konfiskationen og angivet både totalt $o g$ procentvis.

\begin{tabular}{|l|r|r|r|r|}
\hline $\begin{array}{l}\text { Bopæl/hjemsted } \\
\text { Resultat }\end{array}$ & DK & $\%$ & D & $\%$ \\
\hline Afslag, endeligt & 3 & 4 & 8 & 8 \\
\hline Dispensation, 1. ansøgning & 17 & 22 & 49 & 50 \\
\hline Dispensation, 2. ansøgning & 8 & 10 & 12 & 12 \\
\hline Dispensation, 3. ansøgning & 2 & 3 & 4 & 4 \\
\hline Dispensation, 4 eller flere ans. & 1 & 1 & 1 & 1 \\
\hline Disp, forskelig (arvesag) & & & 1 & 1 \\
\hline Betinget/delvis dispensation & 2 & 3 & 2 & 2 \\
\hline Resultat ses ikke & & & 1 & 1 \\
\hline Ikke søgt/ses ikke & 7 & 9 & 17 & 17 \\
\hline Alt udtaget & 30 & 38 & & \\
\hline Arv udleveret & 2 & 3 & & \\
\hline Mere end udtagelsesret & 2 & 3 & & \\
\hline Tildelt uden udtagelsesret & & & 3 & 3 \\
\hline Frigiver småbeløb & 1 & 1 & & \\
\hline Sag frafaldes & 2 & 3 & & \\
\hline Ukendt arving & 1 & 1 & & \\
\hline Domstolsafgørelse & & & & \\
\hline I alt & 11 & & 1 & 100 \\
\hline Heraf tidligere lærere ved tyske skoler & 5 & & 8 & \\
\hline Heraf konsul/diplomat & & & & 100 \\
\hline Arvesager & & & & \\
\hline
\end{tabular}

deres ejendele ikke længere havde nogen - eller kun ringe - værdi. Som noget af et særsyn blev en arvesag prøvet ved en dansk domstol med henblik på prøvelse af, om arveafkald fra tyske arvinger kunne medføre, at deres arvelod kunne tilfalde den danske arving. 
Udtagelsesretten er omtalt ovenfor, og i de »danske sager « har man i 30 af 78 sager udtaget samtlige værdier, og i to tilfælde har man administrativt fået udleveret mere, end udtagelsesretten tillod. I de tre tilfælde, hvor personer, der boede i Tyskland, har fået udleveret effekter trods manglende udtagelsesret, har det drejet sig om gangklæder, linned og andet dagligt indbo, som de angiveligt har haft stort behov for.

I tabel 4 er antallet af dispensationer fordelt efter året, hvor dispensation blev givet, og efter hvilket antal ansøgninger, der havde været indgivet. Samtlige dispensationer er medtaget, således at også de sager, hvor den endelige afgørelse blev en betinget eller delvis dispensation, er medregnet. Som det ses, er den helt dominerende gruppe den, der har fået dispensation ved første ansøgning - 68 ud af $105-$ og det er fra 1951, at antallet af dispensationer stiger markant.

I tabel 5 er illustreret den totale og procentuelle fordeling af sagerne ud fra henholdsvis dansk og tysk bopæl. Under »Tildelt uden udtagelsesret " findes tre sager, hvor tyske statsborgere med bopæl i Tyskland har haft hårdt brug for gangklæder, linned og diverse indbo, og dette er udleveret administrativt på trods af manglende udtagelsesret. Under "Sag frafaldes" er anført to sager, der begge vedrører tidligere tyske statsborgere.

I tabel 6 vises en oversigt over fordelingen af sager, hvor kolonne DK viser sagerne vedrørende de familier, der bor i landet, og hvor kolonne DK(D) viser de familier, hvor ægtemand og/eller søn opholder sig i Tyskland. I sidstnævnte gruppe findes de mest aktive tysksindede, men også her ses, at der i størsteparten af sagerne sker udtagelse af værdierne. I to tilfælde fastholdes afslag.

\section{Den tyske lærergruppe}

I denne kategori findes tolv tidligere lærere ved tyske privatskoler, hvoraf en dog var pensioneret. Som det kan ses i tabellerne ovenfor, udgjorde lærergruppen en ret stor del af de tyske statsborgere i Gråsten retskreds. Det tyske mindretal havde inden for skolelovens rammer oprettet en del nye, tyske privatskoler og i den forbindelse rekrutteret lærere, der kunne bidrage til at fremme tyskheden i landsdelen. Det lykkedes også, bl.a. fordi de rekrutterede lærere af gode grunde var tilhængere af tyskheden og - for dem, der blev ansat efter 1933 - af nazismen, idet det var en forudsætning for i det hele taget 
Tabel 6: Antal sager for personer i Danmark, med særskilt kolonne (DK(D)) for sager, hvor familiefaderen opholdt sig i Tyskland. Sagerne er fordelt efter resultatet efter konfiskationen.

\begin{tabular}{|l|r|r|r|}
\hline $\begin{array}{l}\text { Bopæl/hjemsted } \\
\text { Resultat, endeligt }\end{array}$ & DK & DK(D) & I alt \\
\hline Afslag & 1 & 2 & 3 \\
\hline Dispensation, 1. ansøgning & 16 & 1 & 17 \\
\hline Dispensation, 2. ansøgning & 7 & 1 & 8 \\
\hline Dispensation, 3. ansøgning & 2 & & 2 \\
\hline Dispensation, 4 eller flere ansøgninger & & 1 & 1 \\
\hline Betinget/delvis dispensation & 2 & & 2 \\
\hline Ikke søgt/ses ikke & 5 & 2 & 7 \\
\hline Alt udtaget & 20 & 10 & 30 \\
\hline Arv udleveret & 2 & & 2 \\
\hline Mere end udtagelsesret & 2 & & 2 \\
\hline Frigiver småbeløb & 1 & & 1 \\
\hline Sag frafaldes & 2 & & 2 \\
\hline Ukendt arving & 1 & & 1 \\
\hline I alt & 61 & 17 & 78 \\
\hline Heraf tidligere lærere ved tyske skoler & 10 & 1 & 11 \\
\hline Heraf konsul/diplomat & 2 & 3 & 5 \\
\hline Arvesager & 4 & & 4 \\
\hline
\end{tabular}

at blive ansat. De var dermed med til at forstærke et modsætningsforhold mellem dansk og tysk, der ikke nødvendigvis havde været så tydeligt tidligere. De tyske privatskoler var i frontlinjen for udbredelsen af den nazistiske ideologi. ${ }^{31}$ Mest ekstrem i sit udtryk var måske lærer Asmus Wilhelm Jürgensen, der under pseudonymet Asmus von der Heide fra 1940 skrev sine stærkt antidanske artikler i bl.a. Nordschleswigsche Zeitung i rubrikken "Unsere Stimme«.

Lærergruppen hørte til den gruppe tyskere, der blev betragtet som uundværlige for det hjemmetyske samfund, og de var dermed de sid- 
ste, der blev rekrutteret til militærtjeneste. Af de tolv lærere var en allerede udrejst til Tyskland, tre var anbragt i Fårhuslejren ${ }^{32}$, en var anbragt i Fittinglejren ${ }^{33}$ med henblik på udvisning, en var nægtet indrejsetilladelse til Danmark efter at have deltaget som soldat i den tyske hær, en var savnet siden august 1944, og fem opholdt sig fortsat i Danmark og kunne forvente udvisning, hvis dette ikke allerede var sket.

Trods deres nazistiske overbevisning og stærkt antidanske adfærd havde de tolv lærere samme ret som alle andre tyske statsborgere til at foretage udtagelse af deres værdier.

Af de elleve lærere, der opholdt sig - eller hvis familie opholdt sig i Danmark, fik:

Otte familier udtaget alle deres ejendele.

En familie fik udtaget alle deres ejendele, selvom det overskred udtagelsesretten en smule, idet de fik to bankbøger og deres harmonika med.

En familie fik udtaget de ejendele, der svarede til deres udtagelsesret inden for $2.000 \mathrm{kr}$.-reglen, men herudover »frigav « dispensationsnævnet de resterende ejendele, der bestod af et klaver, to violiner og en lut. En familie udtog ejendele inden for udtagelsesretten og fik i 1947 afslag på deres ansøgning om dispensation for så vidt angår en grund, de ejede. Familien fik dispensation i 1950, hvor de fik udbetalt provenuet af salget af grunden. Familien, der havde bopæl i Tyskland, ejede hus i Gråsten og sommerhus i Kollund. Ejendommene blev konfiskeret, og familien søgte dispensation i 1951, hvilket blev bevilget således, at hustruen fik dispensation den 31. februar 1951 under forudsætning af, at manden overdrog ejendommen til hustruen.

Som det fremgår af ovenstående, fik også erklærede nazister en fair behandling. At to af familierne ret kort efter kapitulationen fik udleveret luksusgenstande som musikinstrumenter, lå vist ikke i kortene, hvis man skulle følge lovens ordlyd. De to sidste familier fik egentlige dispensationer, men da var der trods alt forløbet nogen år, og dispensationspraksis var blevet lempet.

\section{Enkelte udvalgte sager}

Landsretssagfører Linds arkiv over konfiskationssagerne fra Gråsten retskreds beror på Landsarkivet for Sønderjylland. Af de mange sager 
har jeg valgt nogle sager ud som eksempler på, at administrationen af konfiskationsloven var nuanceret og ikke så hårdhændet som påstået. Også personer, der havde gjort tysk soldatertjeneste eller havde været aktive i den nazistiske bevægelse, kunne få dispensation, men der har selvsagt været situationer, hvor et afslag blev fastholdt. De efterfølgende numre er identiske med sagsnumrene i Linds arkiv.

Tre sager, hvori afslag er fastholdt: Numrene 118, 232 og 294.

Tre sager, hvor der flere gange er givet afslag, men efterfølgende givet (sen) dispensation: Numrene 18, 20 og 476.

En sag med en domstolsafgrrelse af arvesag med to tyske og en dansk arving, hvor retten afgjorde en tvist mellem kommissarius og arvingerne: Nummer 126.

En sag, hvor en nazist får dispensation: Nummer 288.

En sag med dispensation på betingelser: Nummer 246.

En sag, hvor en mand, netop hjemvendt fra tysk krigsdeltagelse får dispensation: Nummer 176.

En administrativt besverlig arvesag: Nummer 112.

En sag, hvor udtagelsesretten er »udvidet «: Nummer 40.

En sag, hvor der gives dispensation i en særeje-sag: Nummer 34.

Sag nummer 18 og 20

Disse to sager vedrører samme ejer - en tysk skibsreder ${ }^{34}$ med bopæl i Schweiz. Pågældende var ejer af Grøngrøft gods, Benniksgaard, et græsareal i Søgård og gården Travsted pr. Jejsing. Pågældende ejede endvidere værdipapirer samt andre, ikke helt specificerede, fordringer. Ved registreringen den 13. juni 1949 konstaterede Lind, at der fandtes en del værdifuldt indbo, som enten tilhørte pågældende eller dennes datter. Søsteren til ejendommens bestyrer, der foreviste de værdifulde effekter, oplyste, at hun ikke vidste, om indboet tilhørte gårdens ejer eller dennes datter, der var enke efter en dansk statsborger.

Grøngrøft gods havde et jordtilliggende på 158 ha og blev drevet af en bestyrer for ejerens regning. Bestyreren arbejdede under tilsyn af ejeren af naboejendommen, en tysksindet godsejer. Benniksgaard, der havde et jordtilliggende på 135,5 ha, var bortforpagtet for otte år fra 1. marts 1944, og da forpagteren havde betalt sin afgift rettidigt, og der ikke var hjemmel til ophævelse af kontrakten, besluttede kommissarius efter indstilling fra Lind at respektere kontrakten. Græsare- 


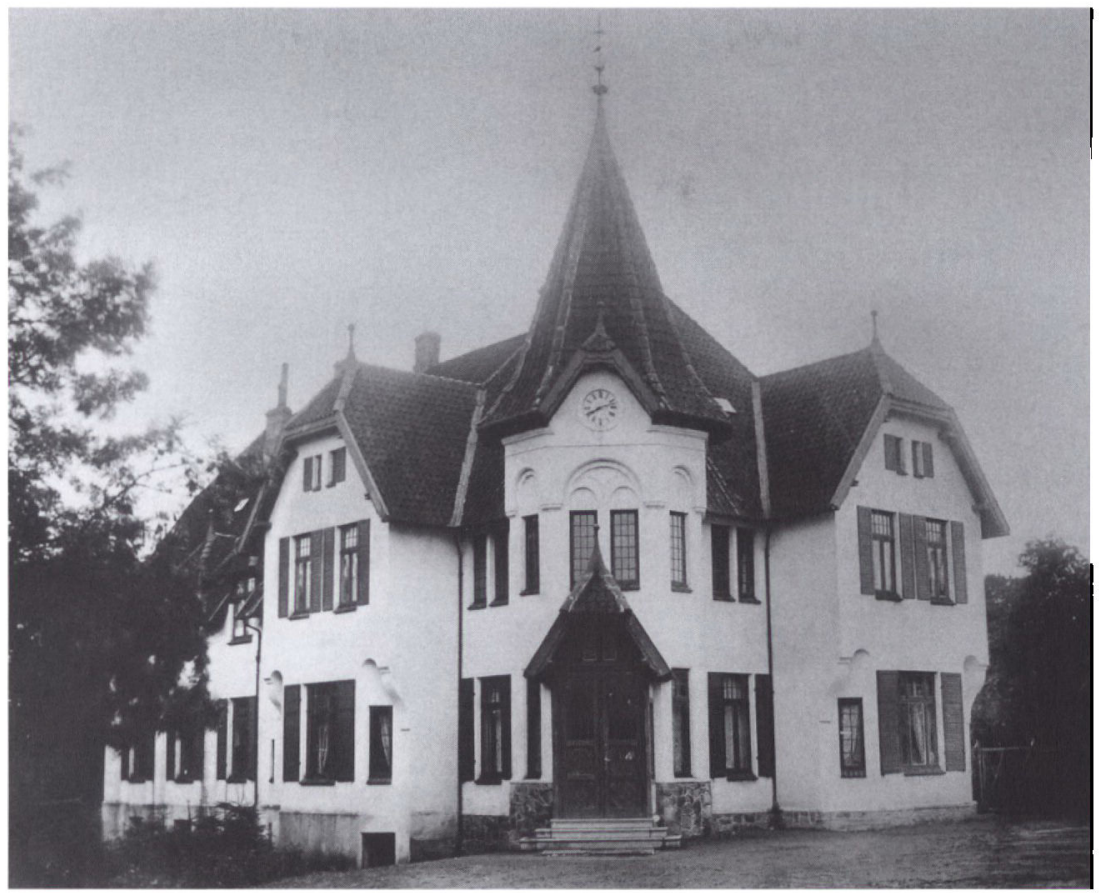

Grøngroft, en af Gråsten-egnens store gårde, der blev konfiskeret og senere omdannet til institution. (Foto: Felsted lokalhistoriske Forening).

alet i Søgaard var på 20 ha og indtil 31. december 1946 bortforpagtet til en kreaturhandler i Aabenraa. Rederens datter havde tinglyst forkøbsret til Benniksgård.

Rederen havde i 1935 købt ejendommene Benniksgård og Travsted af Kreditanstalt Vogelgesang, som dermed fik frigiort betydelige midler til opkøb af landejendomme og udlån til bønder i Sønderjylland som led i jordkampen.

Skibsrederen havde bopæl i Schweiz og ingen personlig tilknytning til sine nye ejendomme og ansatte landsretssagfører Vogelgesang som administrator af sin formue her i landet. Da Kreditanstalt Vogelgesang og Höfeverwaltungsgesellschaft efter krigen blev likvideret, og landsretssagfører Vogelgesang som led i retsopgøret blev fængslet, blev administrationen af skibsrederens formue videreført af Vogelgesangs kontor. Lind havde fra kontoret fået regnskaber, der viste rederens formue, de udestående fordringer samt det beløb, der var kommet ind fra administrationen af Grøngrøft. 
Uvidende om, at skibsrederen telegrafisk 28. maj 1946 havde trukket sin bemyndigelse af Vogelgesang tilbage, gik Lind i god tro ud fra, at Vogelgesang fortsat administrerede formuen. Så sent som ultimo november 1946 sendte Vogelgesang diverse regninger til Lind for at søge midler frigjort til at betale regningerne. Den 23. december 1946 forespurgte Vogelgesang Lind, om han kunne fortsætte bortforpagtningen af græsarealerne ved Søgaard. Han skulle have besked inden 1. januar 1947 (!) og rykkede endvidere for frigivelse af midler til betalingen af de store reparationer på Benniksgaard.

Den 31. december 1946 fik Lind i et brev fra en bankdirektør i Aabenraa underretning om, at forvaltningen af de omhandlede ejendomme allerede for længe siden var overdraget til ham af rederens formueforvalter i Schweiz. Han vedlagde en kopi af skrivelse fra Vogelgesang til en københavnsk overretssagfører, hvoraf det fremgår, at Vogelgesang havde modtaget det nævnte telegram fra rederen. Imidlertid havde Vogelgesang bestyret formuen siden december 1941, og han ønskede nu at blive honoreret for dette arbejde, da han trængte til indtægter, som han i 1947 skrev i et brev til kommissarius.

Efterfølgende orienterede kommissarius den 4. februar 1947 landsretssagfører Lind om, at Statens Jordlovsudvalg ville overtage administrationen af de fire ejendomme.

Skibsrederen boede i Schweiz, havde ingen tilknytning til sine danske ejendomme og ønskede formentlig med sin frigørelse fra Vogelgesang at undgå en konfiskation. Imidlertid var det helt klart, at initiativtagerne til kreditanstalten fra begyndelsen havde set dens virke $i$ et grænseflytningsperspektiv, og at der var kanaliseret store midler fra den tyske stat til kreditanstalten ad forskellige kanaler. Til grund for konfiskationen af ejendommene lå en vurdering af, at rederen var helt klar over, at købesummen for de ejendomme, han havde købt af Kreditanstalt Vogelgesang, indgik i en national jordkamp, og rederen fik da også afslag på ansøgningerne om dispensation i henholdsvis 1950 og 1953 (Grøngrøft) og 1950 og 1952 (Benniksgaard), men opnåede en slags dispensation i 1956 for Benniksgaard og i 1957 for Grøngrøft gods' vedkommende. Da var Grøngrøft gods omdannet til institution, og Benniksgaards jord var opdelt i nye husmandsbrug.

Sag nummer 34

Registrering 24. april 1947. Sagen vedrører et ægtepar med en voksen søn. Hustruen var fra egnen, medens manden var indvandret fra Bay- 
ern i 1920. Parret ejede hus med tilknyttet forretning, idet hustruen ejede ejendommen som særeje, medens møbler og andet indbo, en bil, livsforsikring, sparebevis samt effekterne i værkstedet var fælleseje. Parrets søn havde overtaget og drevet forretningen siden 12. februar 1947. Da sønnen var dansk statsborger, skete der ingen konfiskation for hans vedkommende. Manden var stærkt nazistisk, havde været medlem af Selbstschutz og deltaget i uniformeret og bevæbnet patruljetjeneste; han havde desuden været værnemager i betydeligt omfang og blev overført til Fittinglejren i foråret 1947. Hustruen blev ligeledes overført til Fittinglejren i april 1947. På grund af hustruens særeje blev der indgivet ansøgninger om dispensation særskilt for mand og hustru. 11. november 1948 blev der givet dispensation, formentlig på grund af hustruens og sønnens tilknytning til Danmark.

\section{Sag nummer 40}

Sagen vedrører en familie, der tidligere boede i Aabenraa, hvor politiet foretog registrering den 1. oktober 1946. Bohavet var meget værdifuldt, også for så vidt angik klæder, sengetøj og sølvtøj. Da familiens indbo blev opmagasineret i Gråsten retskreds, modtog Lind sagen i foråret 1947. Lind foretog fornyet registrering 22. september $1948 \mathrm{og}$ konstaterede, at sølvtøj m.v. var udleveret allerede i 1946. Hustruen havde boet i Danmark efter kapitulationen og var forst udrejst 10. november $1945 \mathrm{og}$ havde derfor adgang til at gøre udtagelsesretten gældende. Den pågældende var erklæret antinazist og havde adskillige gange afvist opfordringer fra Werner Best om at melde sig. Selvom han blev stærkt presset, nægtede han at deltage i SS og måtte derfor lade sig indrullere som almindelig tysk soldat. Lind skrev i en indberetning af 15. november 1947 til kommissarius, at pågældende, der ifølge Lind omtaltes meget fordelagtigt af flere danskere, der kendte ham under besættelsestiden, nu skulle tiltræde en stilling hos de engelske besættelsesmyndigheder, og at familien derfor havde brug for sit bohave. Dette blev understøttet af et i sagen beroende, personligt brev fra en politimand, der under krigen havde knyttet venskab med familien, som han omtalte meget positivt. Kommissarius meddelte herefter den 3 . december 1948, at alt registreret skulle betragtes som omfattet af udtagelsesretten, og at samtlige effekter skulle overlades familien. Reglerne om udtagelsesret overskrides hermed klart, men kommissarius har vel skønnet, at den pågældende tyske statsborgers forhold var af en sådan beskaffenhed, at han ville 
få fuld dispensation, hvis der havde foreligget en dispensationsansøgning og kommissarius har ikke onsket at forhale udleveringen af indbo m.v.

\section{Sag nummer 112}

Arvesag. En grosserer afgik ved døden 28. februar 1946. Arvingerne var hans tre døtre, alle tyske statsborgere med bopæl i Tyskland. To af døtrene tog efter faderens død ophold $i$ hans hjem og beholdt hans husbestyrerinde. Som der står i skifterettens beretning, havde faderen en betydelig formue, men der var tilsyneladende ikke helt klarhed over gældsposterne i boet. Døtrene så ingen anledning til at udvise særlig sparsommelighed, førte en ret kostbar husholdning og disponerede frit over kassebeholdningen på $50.000 \mathrm{kr}$. En måned senere trådte konfiskationsloven i kraft, og det medførte, at døtrene ikke længere kunne betragtes som arvinger til boet, der i princippet skulle konfiskeres og overdrages til den danske stat. Dotrene meddelte, at de agtede at søge dispensation fra konfiskationsbestemmelserne, og fik lov til at beholde husbestyrerinden i nogle måneder samt disponere over et beskedent beløb til husførelse. Realisationen af den faste ejendom og indboet blev herefter udsat, indtil der lå svar på dispensationsansøgningen. Døtrene havde imidlertid ikke forstået, hvad konfiskationen betød for forandringen i deres stilling. De inddrog uden videre en $i$ boet registreret bil til privat kørsel - også for husbestyrerinden, der havde ærinder i bl.a. Odense. Bilen måtte så afhentes af skifteretten, der også lukkede af for yderligere forbrug af boets midler. Sagen betød en omfangsrig administration, da der foruden en skattesag var økonomiske mellemværender med både andre firmaer og offentlige instanser. Da døtrene omsider havde foretaget den fornødne ansøgning om dispensation, blev den imødekommet meget hurtigt herefter, og af det, der oprindeligt skønnedes at være et rigt bo, blev det resterende beløb - godt $4.400 \mathrm{kr}$. - udleveret til arvingerne.

\section{Sag nummer 118}

Registrering 4. september 1947. Sagen vedrører et ægtepar med en adoptivdatter. Manden arbejdede i Flensborg, og parret ejede hus med indbo samt en bil. Datterens effekter blev registreret særskilt, og hun udtog alle sine ejendele. Ægteparret foretog udtagelse af en del af indboet og ønskede af de beløb, der måtte realiseres ved salg af 
ejendom eller bil, at blive fyldestgjort op til de $2.000 \mathrm{kr}$., som de havde ret til ifølge konfiskationsloven. Manden henviste til, at hans slægt havde boet i Danmark i 400 år, og søgte dispensation i 1947, 1948, 1949 og 1951. Der blev givet afslag på dispensation, senest i 1951. I en anden Gråsten-sag findes diverse skrivelser, bl.a. et brev af 17. september 1946 fra pågældendes gode ven og nabo, hvori han anbefalede, at pågældende fik dispensation fra konfiskation på grund af hans flid, agtværdighed og pacifistiske sindelag, samt at pågældende bestemt ikke måtte regnes til den del af den tyske folkegruppe, der helt glemte deres forpligtelser som borgere i Danmark. I en efterfølgende skrivelse af 30 . august 1947 tilføjede naboen, at han havde haft besøg af kriminalpolitiet, der havde oplæst en rapport for ham med indsamlede oplysninger om pågældendes forhold. Naboen var ikke glad for det, han havde fåt at høre, men anførte, at manden (i sag nr. 118) efterfølgende over for ham havde tilbagevist, at han den 9. april 1940 skulle have udtalt »wir danken unserm Führer« og bortforklaret, at han i paskontrollen har udtalt "Auf diesen Tag haben wir 20 Jahre gewartet «. Naboen mente fortsat, at pågældende ikke havde indtaget nogen høj militær position, højst været korporal. Naboen undskyldte også hans medlemskab af diverse tyske organisationer, idet han »ikke er beføjet til at udtale mig i så henseende, da man ikke ved, hvor meget en tysk statsborger og særlig en tysk embedsmand var tvunget og pligtig til eller ej«. I sag nr. 118 foreligger endvidere en skrivelse af 30 . september 1952, hvori en anden god ven har skrevet til en lokal folketingsmand og plæderet for bistand til at genoptage pågældendes dispensationssag, da der nu var så mange andre, der ved fornyede ansøgninger havde fåt frigivet deres formue. Sidstnævnte ven anerkendte tilsyneladende heller ikke de fakta, efter hvilke pågældendes ansøgning var blevet afslået, hans militære rang, medlemskabet af NSDAP mv., men betegnede det som sladder, og at man havde forsegt at påvirke pågældendes fortalere. Disse udsagn svækkes på grund af sagernes oplysninger om, at manden havde været medlem af NSDAP siden 1927, været Obersturmführer i NSKK og medlem af andre tyske organisationer, herunder VDA, og at hustru og datter havde været aktive i Frauenschaft. Dispensationssagen blev ikke genoptaget.

Sag nuntmer 126

Sagen vedrører tre arvinger, en søster med dansk statsborgerskab og to brødre med tysk. Hvis arven skulle deles ligeligt, skulle søsteren i 
en sådan sag have udleveret $1 / 3$ af boet, og den resterende $2 / 3$ ville blive konfiskeret med en mulig efterfølgende ansøgning om dispensation. De tyske arvinger havde imidlertid givet arveafkald, så søsteren ville være at betragte som enearving. Dette havde kommissarius ikke kunnet acceptere, formentlig ud fra en forståelig vurdering af, at arveafkaldet var strategi, og han forelagde derfor sagen for domstolene. Dommen lød på, at søsteren skulle være at betragte som enearving, fordi parterne fremførte, at de to brødre havde modtaget noget, der kunne sidestilles med arveforskud. Situationen taget $i$ betragtning er dette en ekstraordinær sag. Kommissarius havde hjemmel til at foretage konfiskation af de to brødres arvelod, men havde valgt at følge spillereglerne $i$ et retssamfund og forelægge sagen til afgørelse af en domstol.

\section{Sag nummer 176}

Registrering 14. marts 1949. Sagen vedrører et ægtepar med to børn. Parret ejede hus, indbo og mekanikerværksted. Manden havde gjort tysk krigstjeneste og kom under krigen i engelsk fangelejr indtil kapitulationen og vendte forst tilbage til Danmark den 21. februar 1949. Manden fremførte, at han aldrig kunne have tænkt sig at melde sig frivilligt, og at han nødtvungent måtte give møde, efter at han blev presset til deltagelse som tysk soldat og tre gange var opfordret til at melde sig. Hustruen havde gennem udlejning og forskelligt arbejde klaret udgifterne til underhold og udgifterne på huset uden socialhjælp eller understøttelse gennem værnemagten. Manden, der havde arbejds- og opholdstilladelse, ville søge dispensation snarest. Ansøgningen blev indgivet $\mathrm{i}$ marts 1949, og dispensation forelå allerede den 15. juli 1949. Det faktum, at manden havde været tysk soldat, betød således mindre end hans forklaring om, at han i realiteten var blevet tvunget ind som soldat. Det har formentlig også haft betydning, at der fra omgivelserne havde været respekt for, at familien havde formået at klare sig selv.

\section{Sag nummer 232}

Registrering 26. august 1948 af indbo, tilhørende tidligere rigsbefuldmægtigede Werner Best med hustru og fem børn. Werner Best var fængslet, men hustruen havde haft ophold i Gråsten også efter kapitulationen og havde derfor udtagelsesret. Hustruen var efterfølgende udrejst til Tyskland, men kom til stede ved registreringen. Hustruen 
fremførte, at parret havde haft en stor del af effekterne med fra Tyskland. Lind foreslog kommissarius at godkende, at pågældende udtog alle sine effekter, placeret $i$ to forskellige villaer, med undtagelse af en badeovn (ikke bageovn) til en værdi af $50 \mathrm{kr}$. Desuden havde hun fået udbetalt $2.000 \mathrm{kr}$. fra provenuet af salg af diverse ægte tæpper. Dette blev tiltrådt af kommissarius. Efterfølgende fremkom en skrivelse af 13. oktober 1948 fra generalstabens kontor i Kollund, der bestred fru Bests udsagn om, at parret havde haft møblerne og indbo med fra Tyskland. Generalstaben fremførte, at "dette indbo er for størstedelen fremstillet og købt her i landet, bl.a. er soveværelsesmøblementet udført af hofmøbelfabrikant C. B. Hansens Etbl. i København«, og at »de omhandlede effekter ingenlunde kan henregnes til indbo hørende til et tarveligt hjem, ligesom kontoret er af den formening, at man med hensyn til udtagelsen er gået udover begrebet: nødvendige indbogenstande «. Imidlertid havde kommissarius tiltrådt Linds forslag og kunne ikke ændre det. En ansøgning om yderligere dispensation blev afslået i 1952.

\section{Sag nummer 246}

Registrering 18. maj 1949. Sagen vedrører et ægtepar med to voksne døtre, alle tyske statsborgere. Parret ejede en forretning med tilhørende butikslokale og beboelse, og hustruen ejede endvidere som særarv efter sine forældre halvparten af en anden ejendom. Justitsministeriet havde i juni 1947 meddelt, at parret skulle udrejse snarest muligt. Registrering af de to voksne døtres effekter foregik i juli 1947, og disses ejendele faldt inden for udtagelsesretten. I januar 1949 fik ægteparret afslag på en ansøgning om dispensation, men den 15. oktober 1949 fik de dispensation for alt andet end selve ejendommen, idet parret dog blev tilkendt brugsret til ejendommen, så længe en af dem var i live. Manden døde i 1950, og efter mandens død opnåede enken dispensation under forudsætning af, at ejendommen blev tilskødet de to døtre, hvilket efterfølgende fandt sted.

\section{Sag nummer 288}

Registrering 7. oktober 1947. Enke med et hjemmeværende barn ejede hus, møbler og andet løsøre samt knap $2.800 \mathrm{kr}$. i banken. Familien var nazister, den afdøde mand blev betegnet som "aggressiv nazist « og hustruen »ivrig «. Børnene var i Hitler-Jugend. På trods heraf blev der givet delvis dispensation i 1948, hvor alt indbo blev fritaget. Her- 
efter konfiskeredes bankindestående samt huset, idet pågældende dog blev sikret brugsret til huset. Brugsretten blev tinglyst. Enken opnåede efterfølgende fuld dispensation i 1952, dog på den betingelse, at hun ikke kunne disponere over bankbeløbet uden tilladelse fra Danmarks Nationalbank.

\section{Sag nummer 294}

Registrering 8. oktober 1947. Ægtepar, begge tyske statsborgere, var stærkt tysksindede og demonstrativt antidanske. Manden opholdt sig i Tyskland, og hustruen kunne ikke få fornyet sin opholdstilladelse. I sagen ligger et brev, dateret 9. august 1948, fra en mand i Flensborg, som var en tidligere nabo fra før Genforeningen. Han mente, at manden blev gjort uret, idet han kun havde beholdt sit tyske statsborgerskab, fordi han dengang købte et hotel i Kappel og som ejer af et tysk skib blev forpligtet til at sejle for tyskerne i krigen, men »ikke som værnemager«. Dette stemmer dog ikke overens med de i sagen i øvrigt foreliggende oplysninger.

Ifølge en i sagen beroende politirapport af 19. februar 1947 var huset hustruens særeje og blev vanrøgtet, f.eks. ved at gulvene blev brækket op, så den danske stat ikke kunne få glæde af det. Hustruen havde udtaget alt indbo, og kommissarius gav tilladelse til, at det blev taget med til Tyskland. Huset blev konfiskeret og solgt, men da der af salgssummen skulle afholdes en lang række større og mindre beløb, som pågældende skyldte både offentlige myndigheder, skorstensfejer og en lang række handlende samt private, var nettoprovenuet såre beskedent. Familien fik afslag på ansøgning om dispensation i 1948, 1949 og 1952.

\section{Sag nummer 476}

1. registrering i denne sag, der vedrører en stor gård, blev foretaget af den daværende bestyrer den 18. april 1947. Gården tilhørte et ægtepar fra Flensborg og blev med sine 145 ha beslaglagt af Statens Jordlovsudvalg. Ejeren fik afslag på dispensationsansøgning i 1948 og 1950. Sagen, der havde været kørt uden for stedfortrædende kommissarius' regi, kom først i 1955 til Gråsten med henblik på registrering, der blev foretaget den 3. juni 1955. Der var nu på ny indsendt dispensationsansøgning. Ægteparret fra Flensborg ejede gårdens møbler og løsøre og anførte, at gården havde været i slægtens eje siden $1488 \mathrm{og}$ at manden hvert år havde brugt gården som sommerbolig og engageret sig i driften. 
Der ligger i sagen en række akter af fortrolig karakter, men af relevans for fremstillingen her skal bemærkes, at den "anbefaling", som pågældende havde vedlagt sin ansøgning, ikke var en egentlig anbefaling om fritagelse for konfiskation, men blot en attestation af fakta (om gårdens drift o.l.).

Pågældende fremhævede, at han ikke var eller havde været medlem af nazipartiet, hvilket havde betydet stor indtægtsnedgang under krigen. Den svenske gesandt i Madrid (en slægtning) erklærede, at pågældende var indstillet mod nazismen, og at han anerkendte 1920grænsen. Gesandten anførte, at pågældende var født $i$ en tysk embedsmandsfamilie, havde fået tysk uddannelse og opdragelse og derfor naturligt nok var tysk tænkende. Mod udtalelsen om, at pågældende anerkendte 1920-grænsen findes modsatrettede udtalelser og erfaringer. Pågældende blev betegnet som "aktiv tysker « og som en, der altid havde tilhørt den fløj, der holdt på Tysklands ubrydelige ret til hele Slesvig.

Pågældende fremførte endvidere, at han blev valgt som formand for sagførerforeningen i Flensborg også med de danske stemmer; men der foreligger i sagen oplysning om, at det enlige danske medlem havde givet udtryk for, at hans stemme ikke måtte tages som udtryk for, at han i øvrigt ville gå ind for pågældende, navnlig ikke nationalpolitisk.

Det var korrekt, at manden havde bekostet mange penge på gårdens drift og forbedringer, men det er noget af en tilsnigelse at kalde gården for en slægtsgård. Pågældendes far giftede sig på sine gamle dage med enken på gården, der var barnløs, og på den måde kom han $\mathrm{i}$ besiddelse af gården.

Gården blev betragtet som en tysk bastion af de lokale, der protesterede mod en eventuel dispensation. "Ejerens" sagfører, der fik adgang til disse papirer, anførte hertil, at protesten var forårsaget af, at underskriverne selv ønskede at erhverve jorden. Det fremgår dog klart af politiets efterfølgende rapport, at nogle få ganske vist ønskede at erhverve jord, men at samtlige underskrivere havde skrevet under af nationale årsager.

Familiens omgang med tyske officerer havde virket stærkt stødende på lokalbefolkningen med heil'en og store selskaber, og den pågældende havde over for de lokale optrådt som overmenneske, ligesom hustruen havde virket stærkt provokerende i sin adfærd. Sagen er omtalt i Hans Schultz Hansens bog om Landeværnet, hvor det anfø- 
res, at der var tale om en oplagt uretfærdighed, at pågældende blev frataget sin slægtsgård, dels på grund af at gården var slægtsgård gennem flere århundreder, dels fordi der angiveligt ikke var noget at sige manden på. ${ }^{35}$ På baggrund af de i sagen foreliggende akter må det siges, at der på daværende tidspunkt var skellig grund til at konfiskere gården. At ejeren så senere opnåede dispensation, var et led $i$ lempelserne i dispensationerne fra 1950.

Gården blev i sin tid solgt med besætning til Statens Jordlovsudvalg, og da pågældende i 1953 igen søgte dispensation, fik han i april 1955 delvis og $\mathrm{i}$ juni 1955 fuld dispensation $\mathrm{i}$ form af nettoprovenuet fra salget af gården.

\section{Konklusion}

Vedtagelsen af konfiskationsloven var præget af et klassisk dansk udenrigspolitisk dilemma. På den ene side ønskede danske politikere goodwill hos de allierede magter - så meget desto mere, fordi samarbejdspolitikken under besættelsen ikke decideret havde fremmet dansk prestige - og på den anden side ønskede man ikke at provokere Tyskland mere end højst nødvendigt. Opfattelsen blandt danske beslutningstagere var, at Tyskland nok var slagent og udbombet, men at landet erfaringsmæssigt altid rejste sig efter sine nederlag og dermed potentielt kunne tænkes at true Danmark igen. Bestræbelsen på at fare med lempe over for Tyskland var således ikke kun motiveret med ønsket om at afsvække spændingerne i grænselandet, men handlede også om dansk sikkerhedspolitik på et mere grundlæggende niveau.

Konfiskationsloven blev gennemført efter pres fra USA og Storbritannien, og Per Federspiel, der var minister for særlige anliggender, måtte tilmed slås for, at Danmark fik adgang til at give dispensation fra konfiskation. Han opnåede ikke en sådan accept, men fik dog aftvunget briterne en indrømmelse af, at Danmark skulle ordne sagen "hjemme", men blot således, at man gik så stille som overhovedet muligt med dørene. På den baggrund var det ikke uforståeligt, at loven kom til at virke hård i sin formulering.

Selvom lovens ordlyd forekom hård, var administrationen de facto mildere end forventet. I administrationen af konfiskationsloven var det helt rimeligt, at de tyske statsborgere, der ikke havde giort noget illoyalt eller provokerende, fik dispensation. Som det er fremgået, fik 
alle, der havde opholdt sig i Danmark ved konfiskationslovens vedtagelse, ret til som minimum at udtage gangklæder, linned og lignende og indtil en grænse på $2.000 \mathrm{kr}$. værdier, der sikrede, at familien ikke var på bar bund. Herudover var dispensationsprocenten høj. Kun $7 \%$ af den undersøgte gruppe fik endeligt afslag på ansøgning om dispensation, og når man gennemgår sagsakterne, er der sædvanligvis en årsag til, at der blev givet afslag. Kun i en enkelt sag har jeg undret mig over, at afslag blev fastholdt, men har ikke kunnet finde frem til de præmisser, der var afgørende herfor.

Til gengæld forekommer administrationen at have været lempelig og i visse tilfælde særdeles mild, når man sammenholder sagsakterne med intentionerne i loven. En del tyske statsborgere, som efter justitsministeriets almindelige praksis skulle have været udvist af landet, fik af humanitære grunde - for eksempel på grund af alder eller sygdom - opholdstilladelse og fik som regel en delvis dispensation $i$ form af livsvarig brugsret til deres huse, livrente, frigivelse af indbo eller en del af den beslaglagte formue mv. Det ses hyppigt, at den endelige afgørelse for denne gruppe tyske statsborgere blev fuld dispensation.

Selvom der i konfiskationsloven eller dens forarbejder ikke var nogen forskel $i$ betingelserne for dispensation med hensyn til fast ejendom og anden formue, har der tilsyneladende været en utilbøjelighed til at indstille dispensation med hensyn til større, faste ejendomme. Dette var tilfældet på landsplan, og det var der også i den undersøgte retskreds. Selvom loven ikke måtte benyttes i jordpolitisk øjemed, var det forståeligt og nødvendigt, at de ejendomme, der var ejet af Vogelgesang og Höfeverwaltungsgesellschaft, blev konfiskeret. Her var tale om selskaber, der var i konfrontation med Danmark om den sønderjyske jord og med en stor tysk kapital i ryggen søgte at fremme tyskheden $i$ landsdelen og danne basis for en grænseflytning. Ud over disse ejendomme lå der yderligere tre større ejendomme i Gråsten retskreds. Med hensyn til disse tre sager skal det bemærkes, at der her lige efter krigen var gode grunde til konfiskation, men at de to ejere af de $i$ alt tre ejendomme efter flere ansøgninger omsider fik dispensation i årene efter 1955, hvor administrationen af konfiskationsloven var blevet markant mildere.

Det, centraladministrationen - eller måske rettere politikerne - kan klandres for, er den tidsmæssigt langtrukne sagsbehandling. Det forekommer også urimeligt, at personer, der for eksempel havde fået deres jord konfiskeret i 1947 og først fik dispensation i 1955, måske 
efter mange forsøg, måtte affinde sig med, at de fik udbetalt provenuet uden renter.

Da det nye Vesttyskland kom til at fungere, blev der herfra selvfølgelig udtrykt harme mod den uretfærdige konfiskation, der stred imod folkeretten. Hjemmetyskerne mente selv, at retsopgør og konfiskationslov var dybt uretfærdig, at Danmark ikke tog hensyn til den nationale loyalitetskonflikt, mindretallet havde befundet sig i, og at tyske borgere var blevet ribbet for alt, hvad de ejede. Disse synspunkter kan findes endnu den dag i dag. Men selvom konfiskationsloven lød hård $\mathrm{i}$ formuleringen, blev der taget særlige hensyn til tyske borgere, og administrationen blev gradvist mildnet.

Administrationen af konfiskationsloven tilgodeså de grupper, de danske politikere havde ønsket tilgodeset, og loven var lempelig for nogenlunde neutrale, rimeligt loyale tyske statsborgere. Loven har i højere grad været restriktiv, når det drejer sig om større landbrug, og den har stort set været konsekvent, når det drejer sig om lovens målgruppe »tysk, fjendtlig « ejendom, idet dog både nazister og personer, der deltog i tysk krigstjeneste og i de herværende tyske korps, har fået dispensation. Loven blev på ingen måde fulgt mere nidkært i Sønderjylland end resten af landet. De sønderjyske folketingsmænd har sandsynligvis bidraget hertil. De vidste, hvad der stod på spil, hvis konfrontationerne blev alt for markante i landsdelen, og ønskede på sigt at medvirke til forsoning og muligheden for et fremtidigt samliv mellem dansk og tysk. Loven har fungeret lempeligt i Sønderjylland, måske mildere end i resten af landet - i hvilket omfang må afvente en anden og større undersøgelse.

Både retsopgør og konfiskation havde love, der lød hårde i formuleringen, men administrationen af de to lovområder blev gradvist mildnet. Der var her en vis parallelitet i tidsforløbet, idet omfanget af dispensationer steg på samme tidspunkt, hvor der skete benådninger i de "store" sager ${ }^{36}$, og hvor dommene i retsopgøret blev klart mildere.

Der eksisterer fortsat mange myter om konfiskationsloven og dens påståede strenghed. En af årsagerne hertil er sandsynligvis den ensidige fremhævelse af enkeltsager. Et par af myterne har været behandlet $\mathrm{i}$ denne fremstilling, der er baseret på et bredere kildegrundlag, og her tegnes et andet og mere nuanceret billede. 


\section{LITTERATUR OG KILDER}

Rigsarkivet (RA)

Kommissarius for konfiskation af tysk og japansk ejendom 1945-1960. Pk. 2-926, 976-992, 994-997, 999-1133, $1137-1143,1150-1211,1216-1322$, 1324-1328, 1349-1351.

Dispensationsnævnets referater.

Journal 347. Revisionsprotokollater vedr. finansår $46 / 47$ og 47/48.

Landsarkivet for Sonderjylland (LA)

Stedfortrædende kommissarius for konfiskation af tysk og japansk ejendom, pakke nr. 1-14.

Privatarkiver: Lind, K. P. A., landsretssagfører, Gråsten

1946-55 Hovedbog (protokol). Arkivnummer 1194.

Retten i Gråsten 1947-1963. Skifteretten. Repartitioner.

Retten i Rodding.

Læg med sager vedrørende konfiskation af tysk og japansk ejendom 1945-46. Primært vedrorende Kreditanstalt Vogelgesang og A/S Höfeverwaltungsgesellschaft.

Skrivelse af 4 . maj 1946 fra kommissarius til dommeren i Frøs Herred.

Følgeskrivelse af 6. maj 1946 fra handelsministeriet til samtlige civildommere.

Retten i Toftlund. Civilret.

Trykt, men ikke mangfoldiggjort materiale: Fortegnelse over herboende tyske statsborgere. Januar 1946. Udgivende instans og trykkested ikke angivet, men oplysningerne hidrører fra de til politimyndighederne indgivne anmeldelser. Fortegnelsen er af handelsministeriet den 6. maj 1946 fremsendt til samtlige civildommere. Biblioteket på Landsarkivet for Sønderjylland, 02.11.3.

\section{Litteratur}

Alnor, Peter Christian: In Schleswig zu Hause. Neumünster, 2003.

Frandsen, Karl-Erik (red.): Atlas over Danmarks administrative inddeling efter 1660. Forlag: Dansk Historisk Fællesråd,1984/85.

Becker-Christensen, Henrik: Det tyske mindretal $i$ Nordslesvig 1920-1932. Bind I + II. Disputats. Aabenraa, 1990
Danmarks Statistik. Statistiske efterretninger, 38. årgang nr. 65. 1947.

Hans Kirchhoff m.fl. (red.): Gads leksikon om dansk besættelsestid 1940 45. 1. udgave. Gads forlag, 2002.

Jørgensen, Stig: "Konfiskation«. Advokaten, nr. 5, àrgang 73. 1994.

Kristensen, Henrik Skov: »Det tyske mindretal og Fårhuslejren - retsopgeret på museum«, Historie 2005, s. 54-110.

Kristensen, Henrik Skov og Inge Adriansen: Als og Sundezed 1940-45. 2. udgave. Haderslev 2005.

Lildholdt, Karen Harder: Konfiskationsloven i praksis. En mikroundersøgelse fra Gråsten retskreds. Kandidatspeciale 2008, Københavns Universitet.

Lorek, Sabine: Rechtsabrechnung - Retsopgor. Politiske Saüberung nach dem Zueiten Weltkrieg in Nordschleswig. Wachholtz Verlag Neumünster 1998.

Lund, Joachim (ed.): Working for the new order : European business under German domination, 1939-1945. University Press of Southern Denmark, Copenhagen Business School Press, 2006.

Lylloff, Kirsten: Konfiskation af tysk og japansk ejendom efter 2. Verdenskrig. Kandidatspeciale 2007, Københavns universitet.

Mortensen, Gunnar Kjær: »Konfiskation af tysk og japansk ejendom ", Fynske årbøger 1998, s. 87-98.

Rigsdagstidende 1945-1948.

Schultz Hansen, Hans: Dansk jord på danske hænder. Foreningen Landezærnet og den nationale jordkamp $i$ Sonderjylland 1927-2002. Skrifter udgivet af Historisk Samfund for Sonderjylland. Nr. 84. Aabenraa 2002.

Schultz Hansen, Hans og Henrik Skov Kristensen (red.): Sonderjylland under krig og besxttelse 1940-1945. Skrifter udgivet af Historisk Samfund for Sonderjylland. Nr. 91. Aabenraa 2003.

Tamm, Ditlev: "Den skandaløse konfiskation af tysk ejendom «, Iyllandsposten 28. april 1997.

Tamm, Ditlev: Retsopgøret efter besættelsen. Kobenhavn 1984.

www.dst.dk/Statistik/seneste/

Indkomst/Priser/Prisberegner.aspx www.retsinfo.dk 


\section{NOTER}

1. Lylloff, 2007, s. 52 ff.

2. RA, i journal nr. 347 , s. 170 . Revisionsprotokollat af 13 . juni 1960 for år 1958/59.

3. Gads leksikon om dansk besættelsestid 1940-45, s. 290.

4. Mortensen, Gunnar Kjær, 1998, s. 8798.

5. Rigsdagstidende, 97. ord. samling 1945-46. Folketinget, spalte $2171 \mathrm{ff}$. Endvidere Lylloff, 2007, s. 52 ff.

6. For orientering $i$ international litteratur, der beskæftiger sig med de tyske bestræbelser på at investere sig til indflydelse på andre landes erhvervsliv kan henvises til Joachim Lund (ed.): Working for the New Order.

7. Rigsdagstidende, 97 . ord. samling 1945-46. Folketinget, spalte 21752176.

8. Rigsdagstidende, 97. ord. samling 1945-46. Folketinget, spalte $2270 f$.

9. Rigsdagstidende, 97. ord. samling 1945-46. Folketinget, spalte 2286. Lovforslagets $\S 3$, stk. 2 .

10. Lylloff, 2007, s. 57.

11. Konfiskationsnævnet havde fem medlemmer, udnæunt af Handelsministeren.

12. Jens Herfelt blev udnævnt til dommer i Østre Landsret i 1945 efter under krigen at have været kontorchef i Justitsministeriet.

13. RA. Pakke 926. Sag 434. Personaleopgorelsen findes i skrivelse af 21. maj 1959 fra kommissarius Herfelt til Handelsministeriet.

14. RA. Pakke 926, sag nr. 434.

15. Ved fremskrivning efter Danmarks Statistiks "prisberegner" svarer $2.000 \mathrm{kr}$. til godt $38.000 \mathrm{kr}$. i nutidsværdi. Da "prisberegneren « ikke kan benyttes uden videre i denne sammenhæng, er der ud fra lønstatistikkerne fra Danmarks Statistik, Statistiske efterretninger, 38. årgang nr. 65, foretaget en beregning ud fra lønniveauet i 1946, der viser, at de $2.000 \mathrm{kr}$. svarede til 15 ugers løn for faglærte mænd, 17,5 uger løn for ufaglærte mænd og 25 ugers løn for kvinder.
16. Dette og det følgende afsnit er baseret på Rigsdagstidende for så vidt angår selve konfiskationsloven, herunder processen frem til vedtagelsen af loven, og på gennemgangen af Gråstensagerne og de tilsvarende centraladministrative sager samt dispensationsnævnets referater samt diverse revisionsprotokollater for så vidt angăr administrationen af loven og dispensationspraksis.

17. RA, journal 347. Revisionsprotokollat vedr. finansår $46 / 47 \operatorname{og} 47 / 48$, s. 20

18. Dispensationsnæunet bestod af 7 medlemmer. Handelsministeren udpegede to medlemmer og Udenrigsministeren, Finansministeren, Indenrigsministeren, Justitsministeren og Ministeren for særlige anliggender udnævnte hver et medlem.

19. Domænegårde er gårde ejet af staten og drevet af en forpagter.

20. Hans Schultz Hansen, 2002, s. 14.

21. Henrik Becker-Christensen, 1990, s. $138 \mathrm{ff}$.

22. Den såkaldt "truede firkant « var det område, der lå mellem Højer, Logumkloster, Aabenraa og Gråsten

23. Hans Schultz Hansen, 2002, s. 119.

24. LA. Retten i Rødding. Skrivelsen fra Statens Jordlovsudvalg er med sikkerhed udsendt til samtlige retskredse i Sønderiylland.

25. Hans Schultz Hansen, 2002, s. 119.

26. Henrik Skov Kristensen og Inge Adriansen 2005, s. 272 ff.

27. Henrik Skov Kristensen og Inge Adriansen: 2005, s. 272 ff.

28. Henrik Skov Kristensen, 2005, illustration s. 94.

29. RA. Pk. 918. Sag 347. Revisionsprotokollat af 6. juni 1950 for $1948 / 49$.

30. Beregnet ud fra 78 familier med sædvanligvis 2 voksne personer $i$ hver familie samt $i$ enkelte familier hjemmeboende, voksne børn.

31. Hans Schultz Hansen: "Sindelagskamp og samarbejdspolitik ", i Sonderjylland under krig og besættelse 1940-1945, s. 47.

32. Den tidligere Frøslevlejr var nu om- 
dannet til straffelejr under navnet Fårhuslejren

33. Flygtningelejr i nærheden af Vorbasse.

34. Sagerne er behandlet hos Hans Schultz Hansen, 2002, s. 119 f.
35. Sagen er behandlet hos Hans Schultz Hansen, 2002, s. 120.

36. Werner Best, hvis oprindelige dødsdom blev konverteret til 12 års fængsel, blev i 1951 benådet og udvist af Danmark. 
